〔農村医学 23巻 5 号 580 618頁 昭. 50.3〕

会員講演

注）演題の番号は，発表順位

\title{
消化器疾患 I
}

1．広島県下の農村で行なった胃集検成績

広島県 尾道総合病院 光 波 康 壮 - 他 5 名

2. 秋田県一農村における胃がん死亡0 对策の成果について 秋田県 由利組合総合病院 佐々木志保子・他 4 名

3. 農漁村・僻地におけるファイバースコープ胃集検

北海道 勤医協札幌病院 仲紘 嗣 - 他 1 名

4. 秋田県南部における消化器癌について

..秋田県 平鹿総合病院農医研 加 藤 晶，平・他 5 名

5. 農協の健康管理活動について一一本成人病予防会活動を中心に一

日本成人病予防会 杉 山 義 数. 他 2 名

追加. 当施設における胃集検の実態と検討

静岡県 遠州総合病院 多 米 英介・他 6 名

座長 秋田県 平鹿総合病院長 林茂 樹 長野県立阿南病院長宇治正美

$5 つ$ 演題を, 内容的に大別すると，1，5 ほ精密 検査の受診率の低い点を指摘して, 啓蒙の努力と実施 方法の改善点に言及した。2，3はファイバー集検を 実践した 5 年間の体験にもとづいて，その有効性と， 受検者の心理分析にまで考虑を払つた仕事の報告であ った。 4 は, 過去 5 年間の消化器癌の検討を行って町 村別の特異性について今後の地域問題を提示した。

以上に対して，集検の有効性が臨床的に実証された 成績が追加発表された。

1 で，光波(広島・尾道)は，集検で要精検となった 人々が，実際に受診する率が $47.2 \%$ にすぎない点を指 摘し，この中には，精検完了の報告もれも，多少はあ るだろうが，それにしても少いと言う。中でも，70才 以上の高令の受検者についての必要性の反省も, 言外 にほのめかした。このような害の中で，住民の意識 の低さと集検実施側の充実を求めた。

5 で, 杉山(全厚連)は, 同じく精検の低率の原因と
して, 無自党症状者, 病院に遠い人, 指定された日の 非受診, 高年令者のあきらめ, 受診がこわいという心 理をあげて，農協を中心として，地域に協議会を作る ことを提示した。

以上に対し, 松下(静岡・厚生)は市町村保健婦, 協生活指導員のチームで追跡調查, 実施機関からの報 告の亭行等によって精検率 $90 \%$ の成績をあげたことを 報告した。中目(秋田・由利) は, 小地域癌診療圈を作 って, 地域内の開業医方に参加してもらい, 共同読影, 勉強会を行うなどの努力をし, 地域内の要精検者を診察 する方法を示した。林(秋田・平鹿)も地域病院の相互 連絡の必要性を言い, 中目の方法を一歩すすめて, 指 定医とは言わぬが，せめて登録医制をつくったらどう かと提言した。いずれも大切な発言である。

2 の佐々木(秋田・由利)は, ファイバー集検の併用 によって好結果を得たことを示し, 検診と並行して食 事指導を行い, 塩蔵食品の減少, 米中心から, 肉, 牛 
乳摄取のすすめによって，胃癌減少の傾向のあること を示した。なお，出稼者や勤務者が，集検に参加でき ない点を指摘した。

3で，仲(北海道・勤医協札帽)はファイバー集検を 強力に実施して, 本法によらねば発見不能の疾患をも 把握し, 受検者の心理をも考虑して, 本法の苦痛が, 意外と少いこと，また，経験をかさねるごとに，受検 者が慣れてゆく点に言及した。

上の二つの発言から, 一般に, 苦痛を伴う検査法と して様われがちな内視鏡検査が, 意外となめらかに行 われるということが, 改めて認識された。しかし，そ れには，実施者側に，それなりの努力が払われている わけで，仲らは 4 人の術者が 4 時間かけて 120 名を検 査するという手ぎわのよさであり, 由利病院では, 早 朝行うという配虑を行っている点が胸をうつ。

4 の加藤 (秋田・平鹿) は, 過去 5 年間の消化器癌を 検討して, 臓器別のみでなく, 農・非農別, 町村別, 男女別に特異性を追究した。この中から，町村によっ て胃癌の発生の異ることを知ってここに今後の課題に 出会った。また食道癌の頻度と自覚症状を詳細に観察 した点は，食道集検への方向づけになる。

全体的にみて, 多米(静岡・遠州)は追加発表して, 集検胃癌と外来患者胃癌とでは，根治手術の可能度に 前者で $90 \%$, 後者で $39 \%$ という大きな有意差を体験
し，したがって早期胃癌の発見率も，集検癌において 明らかに多いことを, 臨床経験をとおして実証した。 この報告は，集検の有効性にためらいを持つ者に対し て自信を与えるものである。

まとめ (1)要精検の受診率の低いという点。胃集検 が行われるようになって，何年もたち，その実施方法 が定着してきているにもかかわらず，いまだにこの点 が指摘されることは残念である。これは集検を実施す る側の追跡, 連絡, 訪問等によって解決する他に道が ないであろう。保健婦の指導と教育の力はとくに期待 されるところである。

(2)胃集検をすすめる主体を明確に認識することの必要 性。これによって, 精検者の動向を把握できるであろ う。集検の仕事は, 住民の啓蒙によって, 効果が上が る面が多いので，教育の実施を考える。

(3)精密検査を完全実施し，また精度を高めるために， 指定医療機関，あるいは，登録医療機関という方法を 考える必要が生じてきたようである。包括医療の立場 からも，この点は地域ごとに研究することがのぞまし い。

(4)マンネリズムにおちいらぬためには, 成績のまとめ により反省し，ファイバーその他の有効技術を活用する 志向が求められる。

\section{消化器疾患 II}

6. 胃集検の問題点——特に非胃癌疾患の治療管理について—

静岡県 静岡厚生総合病院 岡昭・他 3 名

7. 胃集検における保健婦の在り方について

・長野県 飯田保健所阿南支所 丸井きのえ・他 2 名

8. 胃 X 線精検時の患者被曝防護の試案

長野県立阿南病院 小野寺司・他 3 名

9. X 線検査時における患者の被曝について

静岡県 静岡厚生総合病院 吉 川雪 男 - 他 5 名

座長 長野県 佐久総合病院副院長 三 井 善 之 助

6，7で，胃集検は被曝の点から，20３0代の人に はやめたいとの追加発言に私も賛成する。文献にも,
その上発見率も低く，能率も悪く中止すべきだとある。 岡(静岡・厚生)の精検受診率 $96 \%$, 癌発見率がだん 
だん減少していること, 進行癌が減ってきていること 等は, 立派だと思う。精検脱落者の中から5名も癌患 者が出ていることは私等多かれ少なかれ経験すること, 留意すべき事と思う。丸井(長野・飯田保健所)の保健 婦の役割について, 私は集検の全経過を通じてもっと 高く期待したい。丸井の場合も精検受診率が高い。文 献によると大都市より町村部の方が集検による早期癌 の発見率が高いこと,これは, 我々農村医学会は大い に期待してよいのではないか。丸井は胃炎の問題につ いても触れておられるが, この点についても, 私等は 考虑すべきことと思う。
8，9の患者の被曝の問題については，私等が日常 診療について留意すべきことを指摘していただいて感 謝する。以前結核の多かった時代，医師のレ線被懪に ついては問題になっていたが，患者の被曝については 問題になっていなかった。当時米国においては，すで に患者の被曝について一人工気胸の前後のレ線透視 で患者が被曝することが論ぜられていた。その後久し く被曝について余り関心がなかったが，最近患者の人 権が尊重されると共に患者の被曝について問題とされ るにいたったことは結構なことである。私等の日常の 診療でこれを大いに考虑しなければならない。

\section{消化器疾患 II}

54. 長野県下農民の集団健康スクリーニングによる肝機能検査の結果

$$
\text { 長野県 佐久総合病院 寺 島 重 信 - 他 } 5 \text { 名 }
$$

55. 熊本県下の農業従事者の肝機能検査成績の検討

熊本県健康管理協会 滝 口他10名

56. 農村病院における肝炎 B 抗原

長野県 佐久総合病院 藤 田 公 生・他 1 名

57. ヘパトームの外来スクリーニングとしての $\alpha_{1-}$ フェトプロティン測定成績

秋田県 由利組合総合病院 三浦 幸一郎・他 4 名

58. 当院における直腸癌症例の検討

長野県 佐久総合病院小諸分院 坂 本 和 夫-他 3 名

座長 東京慈恵会医科大学教授出田欽 静岡県 清水厚生総合病院長 金 田 丞 亮

寺島らは自動分析装置による肝機能検査を行ない, 職種別に性, 年令による異常の出現率について報告し, その結果異常の出現は男女共に農業専従者に少くて他 職種の男子に多く見られたとした。

滝口らは, 熊本県下農業従事者の生産別にみた地帯 区分, 性別, 年令, 季節差による異常の出現率につい て報告して果樹, 養蛼, 八ウス園芸の複合地帯に特に 高い異常が出現して男性で高令者ほど異常出現率は高 く, 農㢣期に異常者が出現している。肝障害について は疲労度, 生活環境, 従事する仕事等従来種々の要因 が複雑にからみ合っているとされているが農業と農業
従事者の疲労を探る一つの手がかりと考えて検討して いる。

藤田らは肝炎 HB 抗原の追求調査を本年は医療従事 者について検討して抗原, 抗体について従来の報告と 異なり, 透析室, 手術室で特に高い抗原, 抗体陽性率 が認められなかったとしている。又人事交流の多い職 場間においても職場における一方から他方への感染を 否定している。このことは従来報告され推定されてい た HB 抗原陽性者による伝染径路に大なる問題を投げ かけ今後の検討に期待を持たされる。

ついで三浦らは $\alpha$-フェトプロテイン (AFP) のラジオ 
イムノアッセイ(RI)によるAFP の定量測定を行ない肝 癌, 胃癌特に肝転移癌に高値陽性を示しているが原発 性肝癌における定量值は高低いろいろあって肝癌の診 断には肝シンチスキァンニング, 腹腔動脈造影法等を 併用しての診断が必要であり又肝癌及び他肝疾患につ いて継時的測定の必要を述べていた。

さらに坂本らは日本において増加しつつある大腸癌
について, 内視鏡を使用して直腸の進行癌, 早期癌, 腺腫様ポリープの 3 群につき比較検討して早期癌, 腺 腫様ポリープの診断につき従来の指診のみによる発見 率は極めて低く, 肛門部より出血の訴えある患者に総 て内視鏡検査を行なう早期発見法早期治療を訴えてい た。人間ドック検査部門に採用する要があるとしていた。 なお，質問追加討論は都合により省略す。

\section{循環器疾患 I（脳卒中）}

10. 秋田県由利本荘地方の脑卒中病型の年次推移

$$
\text { 秋田県 由利組合総合病院 伊 藤 政 志 - 他 } 7 \text { 名 }
$$

11. 秋田県由利本荘の脳卒中一 24 時間以内入院脳卒中の予後—

秋田県 由利組合総合病院 伊 藤 政 志 - 他 5 名

12. 秋田県の在宅脳卒中患者リハビリ学級

$$
\text { 秋田県 由利組合総合病院 伊 藤 政 志・他 } 1 \text { 名 }
$$

13. 中伊豆温泉病院における最近 5 年間におけるリハビリテーションの実態

静岡県 中伊豆温泉病院 間 得 之・他 2 名

14. 脳血管障害患者の退院後の管理

静岡県 中伊豆温泉病院 大土井淑朗・他 5 名

15. 脳卒中患者登録方式の試みと，その追跡によるリハビリ指導の検討（第 1 報）

長野県 佐久保健婦会 菊池やす子・他 5 名

16. リハビリテーションにおける心身医学的接近

秋田大・心療センター 長谷川直義・他 5 名

追加．農村における脳卒中患者の看護，退院患者の生活状況について

·長野県 佐久総合病院 仲沢美枝子・他 4 名

$\begin{array}{lllllll}\text { 座長 全国共済連医務部長 } & \text { 井 } & \text { 上 喜 } & \text { 美 } & \text { 雄 } \\ & \text { 長野県 } & \text { 鹿教湯温泉療養所長 } & \text { 藤 } & \text { 田 } & & \text { 勉 }\end{array}$

$10,11,12$ は 3 題とも伊藤 (秋田・由利等)の報告で ある。10は, 由利本荘地方における脳卒中発症を過去 10 年間の死亡票により調査した。これによれば, 全脑 卒中数が明らかに隇少しており, また出血対硬塞比の 逆転がみられ, 出血の減少をみているが, 実際剖検例 においてもこれを裹付ける成績であった。しかし，49 才以下の若年者脳出血数は必ずしも減少していないこ
とを警告した。この演題に対し, 磯村(長野・佐久)は 臨床診断の正診率に関する質問があったが，伊藤は一 般正診率は $80 \%$ 以下であると回答した。11では，同 地域の 24 時間以内入院脳卒中例の予後を調查し, ICU 管理は予後に大した影響を及ぼさないが, 脳出血例の 適応の選択により手術療法を行えば, 死亡率減少と A DL 独立獲得に有効であると報告した。磯村はこの演 
題に意識障害程度判定時期と手術療法と保存療法例の 年令構成に関する質問があり，これに対し伊藤より意 識障害度は入院の時点で判断し, 手術療法より保存療 法例が，平均年令が 5 〜 寸多いと回答した。

12では, 由利本荘地域在宅脳卒中患者のリハビリ学級 の 4 年間の成果を報告した。この学級への参加は当初 の 83 名から 1,002 名に増加し, その 155 例に要入院リ 八，または装具を必要とした。各指導医もこの学級制 の有効性を認めているが，地域が限定されること，ま た寝たきりの人は対象にならないこと，および地元医 の協力が得られていない等の問題点を提起した。浅利 (秋田・湖東)は，この問題に次の追加を行なった。同 氏もリハビリ学級を行なっており，参加者は孤独な老 人障害者が多く，訓練というより話し合いや共同作業 および娛楽が喜ばれる傾向があること，心理的な面か らのアプローチの必要性があるとした。

13 では, 同病院における最近 5 年間のリハビリの実 態を報告し，利用者数の増加と共にリハビリチームの 增員の必要性とともにアンケート調査により退院患者 の家庭での ADL が退院時よりも低下する患者もあり， また全体の就職率 $17.9 \%$, 特に失語症例では $14 \%$ と低 率であり，中間施設設置の必要性を強調した。

14 では, 同病院でリハビリを受けて退院した脳血管 障害患者はその ADL 保持のためには退院後の主治医 と担当地域保健婦との三者の緊密な連絡の必要性にも かかわらず，現実には72\%の家庭は保健婦の訪問を受 けておらず，22\%は医師にも保健婦にもかかっていな いと報告した。これに対し長谷川(秋田大)より，少人 数のナースおよび保健婦では，患者との対話が不充分 で社会的，心理的アプローチをどのようにしているか との質問に対し，大土井は不足ながらナースもリハビ リに積極的に参加しており，また退院後は保健婦に依存 するのではなく，チームの範囲を拡げているのである と回答した。
15，横山(佐久保健婦会)は，佐久地方では，佐久病 院内に情報センターを置き医師会, 保健所, 保健婦会 が有機的に連携をとる脳卒中患者登録方式について報 告した。これにより患者の脳卒中発症原因と様式およ び経過，とくに 3 週後， 3 ケ月後および 1 年後の症状 経過の把握がきわぬて容易になり，今後の地域患者の 追跡指導に大きな期待が持たれた。この演題について 磯村は，佐久地域における脳卒中の発症ならびに追跡 調査を追加した。脳卒中発生は 70 79 才がピークで あり，月別には冬から春にかけて多く，外来治療 3 週 間以内死亡率 $65.0 \%$ に対し，入院死亡率は $28.0 \%$ で あると報告した。この追加に対し，伊藤(秋田・由利) より，佐久病院の症例数と剖検による正診率の質問が あり，演者は，佐久病院入院数は $208 / 558$, 剖検率 60 $\%$ ，診断正診率 $84 \%$ であると问答した。

16 では, 各種脳血管障害後遺症患者のリハビリテー ションに心身医学的アプローチの必要性を強調し，患 者のリ八訓練には治療陣との好ましい人間関係が望ま れ，心理療法の併施が必要であることを強調し，また 具体的に匂いによる治療効果があがる成績を示した。 追加として，仲沢他(長野・佐久)は, リハビリ病棟退院 後の患者の家庭訪問による.調查を報告した。退院患者 の約半数は ADL上何らかの看護者を必要とし, 経済 的および家庭的問題になる原因であるとし，また家屋 改造面においてもトイレの改造はかなりされているが, 風呂の改造は 42 人中 9 人に実施されているに過ぎな かった。この問題につき田谷(茨城・土浦)および浅利 (秋田・湖東)から発言があった。田谷は, 老人ホーム, 特別養護老人ホームへの脳卒中患者の退院先としての 利用をすすめられ，また浅利は家庭環境の悪化が退院 患者の ADL に悪影響を及ぼしていることを指摘した。 最後に豊田(金沢大)より地域りハビリテーション充実 のためのパラメディカルスタッフ養成増員の必要性と 協力方の依頼発言があった。 
126. 上野村における住民健康管理一一日尿中食塩排泄量調査成績一

群馬県 藤岡保健所 大 月 邦 夫・他 6 名

127. 秋田県平鹿地方における脂質代謝について (第 6 報), 動脈硬化性疾患における

リポ蛋白分画の検討……秋田県 平鹿総合病院農医研 佐々木 司 郎・他 5 名

128. 都市近郊農村における脂質代謝について（第 3 報）

愛知県 海南病院 下 村 尚一・他 6 名

129. 新鮮脳出血, 脳血栓, 心筋硬塞と血小板凝集能の関連について

長野県 鹿教湯温泉療養所 小林 逸 郎・他 3 名

座長 愛知県 愛北病院長 伊 藤 恭 平

本群の内容は, 尿中食塩排泄量, 脂質代謝 ( 2 題), 血小板凝集能に関する調査, 計 4 題であった。

まず大月らは, 群馬県西南部過踈地域(上野村)住民 に対して, 一日尿中食塩排泄量を測定し, 食塩捸取状 況との関連をもとめ, 住民の健康管理, とくに高血圧 を中心とした循環器疾患の発症防止の一助として, 本 法は住民に対する食事指導の一指針たりうると報告し た。次に，佐々木らは，長年秋田県平鹿地方における 脂質代謝動態について検索をすすめてきたが，今回は 動脈硬化性疾患を中心に血清コレステロールおよびト リグリセリドと対比しつつ, リポ蛋白分画異常について 検討し, 心疾患群, 脳硬塞群に pre $\beta / \alpha$-リポプロティ ン比の高いことなどを報告し，また下村らは，名古屋 市近郊農村地帯における農民の脂質代謝について，過 去 3 年間にわたる年次的経過の成績についてのべ, 血清統コレステロール值の年々の增加と, それが食品 搨取状況に関連のあることを想定した。次に小林らは 血小板凝集能と脳出血, 脳血栓との関係について検討 を加え,これら脳疾患および高血圧患者の血小板凝集 能值は, 健康者に比し高值を示し, また, 新鮮脳出血 患者のそれは, 血栓症にくらべ低值を示すことを報告 した。

追加討論については, きわめて活発で, その二, 三 をあげれば, 堀部(名大・予防医学)は, 栄養調査成績 とナトリウム排泄量との関連について質問し, 大月は 搨取食品中の食塩の尿中排泄率は約 $80 \%$ とのべ，ま た鈴木(秋田・農村医学研)は, インスタントラーメン
中に食塩量の多いことをとりあげ, 食事指導のきめこ まかさの必要性について追加した。次に清水(長野・松 代)は, 心筋硬塞のさい， $\beta$ リリ゚プロティンについて は年令別の変動がみられるとのべ, 一方, 佐々木の共 同研究者, 林(秋田・平鹿)は, 心筋硬塞では $\alpha$-リポプ ロティンの減少, pre- $\beta$-リポプロティンの増加, また 若年者, 低血圧者ほど脂質との関連が強いと追加した。 さらに磯村(長野, 佐久)は, 長野県八千穂村住民のコ レステロールレベルは, 上昇を示してはいるが，なお それほど著明ではない。しかし 40 才代男性の増加が著 しいとのべ, 一方清水は, 血小板凝集能值について, 脳血管損傷発生以前の関係について質問し, 小林は, 症例のつみかさねにより脳卒中の予後判定, 発症の予 知に資したいとした。

伊藤(座長)は, 本総会における特別講演「老化の生 理」のなかで, 山田弘三先生が, 老化防止の最大の眼 目は動脈硬化の撲滅であり, その対策として代謝, 細 胞, さらには分子レベルでの検索が今後ますます重要 であることを力説されたこととあわせて, 農村医学に おける循環器疾患の研究方向も, たんに疫学的調査に とどまらず，こうした流れに志向しつつあること，ま た, 動態観察上の精密度を加えつつあることに共感を 賞えるとともに，農村における循環器疾患の予防対策 確立, さらにはその診断, 治療, リハビリテーション に対する一道程として, 今後ますますの御精進を各演 者にお願いして，この群のむすびとした。 
130. 循環器疾患管理と二, 三の問題点について

長野県 国保長門町病院 矢 島嶺・他 2 名

131. 農山村循環器管理と保健所のやくわり(第 2 報)，脳卒中予防対策事業の効果と問

題点…………………………島根県 松江保健所 石 川 - 代

132. 循環器管理における知見—CTRとR High Voltage との関係—

静岡県 静岡厚生総合病院 近 藤 照夫・他 5 名

133. 農村高血圧症の研究——容積脈波と脈波伝達速度について (2)

神奈川歯大・内科野田喜代一・他 1 名

134. 農作業負荷時の異常心電困の検討とその追跡調査

長野県 松代病院 清 水 善 次 - 他 4 名

座長 香川県 滝宮病院長 小 野 田進 愛知県 海南病院長下 村 尚 -

農村の老令者增加は, 日本人全体の傾向とともに, 若年者の都会流出の結果，ますます顕著になっており， とくに高令者の循環器管理については, 今から真剣に 取組まなければならない重要な課題であることは言を またない。専門家の予測するごとく, 我が国民の循環 器疾患による死亡は, やがて欧米人並みに到達する傾 向のある時, 循環器疾患 四群 $(130 \sim 134)$ とその追加討 論において, その管理の方式と方法について, 基礎デー 夕を元にして論ぜられたことは，まことに時宜を得た ものと敬意を表したい。

先ず 130 矢島らは, 健康管理センター活動として, 3 年間にわたり, きめこまかい検診・指導・治療を実 施し, 中年期の循環器疾患の早期発見, 早期管理の必 要性を立証され，131 石川らは保健所職員の立場から, 変動する農業の労働, 生活, 食事についての検討の必 要性をとき, 保健所体制の充実を求め, 巾広い活動を すべきであるとしている。132近藤らは, 循環器検診 において異常者の血圧, l-R 高電位および ST. T 異常 が CTR と如何なる関係があるか検討され, 長期観察 をする場合なにか良い指標になるのではないかと思わ れた。133野田らは, 容積脈波と脈波伝達速度につい て, 長年にわたる一連の研究の一部として報告され, 農村循環器検診に如何に応用されるか苦心の跡がうか がわれた。向後さらにより良い方式探究に御努力され ることをお願いしたい。134 清水らは, 農村の潜在的
虚血性心疾患の発見に, 本年は QT 時間のほかに, TP 時間の計測をとりあげ検討されたが，氏らの多年にわ たる長期観察の結果が示され興味ある報告であった。

以上により, 前 2 席について言えることは, 検診・ 指導を受ける側の正しい認識と積極的実行とが要望さ れ，また，実施側の体制強化も強調された。またここ のためには, 後 3 席で循環器疾患の予後判定にきわめ て有利な検査方法を検討され，第一線の医師が自信を 持って農民の指導にあたることができるより所を示さ れたものと考え，今後，ますますこういった研究を積 みかさねて頂き, より成果あるものにして行くべきだ と信ずる。

なお，質疑応答・追加は下記のごとくであった。

(1) 越知 (長野·長門町) は, 閉経期に ST. T 变化の出 現率が高いが, 男性にもこの傾向があるのは今後検討 したいとし，(2)伊藤(秋田・由利)はl-high R S ST. T 変化の重なったもので検討してはの発言あり。また, 林(秋田・平鹿)は, 伊藤発言には年令構成を考虑に入 れるべきだとした。(3) 堀部(名大・予防医学)は133に 对して, 脂質や心電図との関係を質し, 動脈硬化の指 標としては, 細動脈硬化とアテローム硬化といずれに 関連が深いかとの問いに対して, 脈波伝達速度の測定 は動脈硬化度，あるいは全血管抵抗の綜合的指標とし て役立つものと考える旨答えた。(4)野田(神奈川歯大) は, 潜在的虚血性心疾患の発見には運動負荷時のST.T 
変化以外の指標として QTc, TP 間隔，VGを試みる のならば, 結局, 心機能のチェックということになり, QT ratio, QT $/ T Q$, 容積脈波から算出する心機能指数
=心拍効果 $\times$ 心力系数，心室群の綜合指標になる VG などが役立つとし，ただ VG は計測が面倒で誤差も多 いと追加発言した。

\section{呼吸器疾患}

17. 農村住民の肺活量と最大呼気流量について

東京医歯大・難治研疫学 栗 原 洋 子 - 他 4 名

18. 農業従事者の肺機能に関する考察 熊大医・公衛 上田 厚・他 3 名

19. 山村における気管支肺疾患（第 1 報）一一各種疾患の罹患状況—

…千葉大・農医研，佐久間町国保山香診療所 海 老 原

勇

20. 山村における気管支肺疾患（第 2 報）じん肺症

…千葉大 ・農医研, 佐久間町国保山香診療所 海 老 原

勇

21. 本邦農村地帯の花粉症についての臨床的研究

長野県 佐久総合病院 神 辺譲・他 4 名

22. 農村地域における特発性気胸について一一佐久総合病院10年間の症例から一

長野県 佐久総合病院 陶棣 土・他 6 名

$\begin{array}{llllll}\text { 座長 } & \text { 岐阜県 } & \text { 昭和総合病院長 } & \text { 黒 岩 } & \text { 秀 } \\ & \text { 秋田県 } & \text { 仙北組合総合病院長 } & \text { 五 } & \text { 嵐 } & \text { 卓 }\end{array}$

17 では, 昭和 47 年静岡県山村地区住民を対象として の集団検診に肺活量と最大呼気流量を測定したところ, 両者とも男女差で明らかな相異を示し, 年代別では 60 才 代が低下することが報告された。呼吸器障害発兒のため の一つの screening として, 肺活量・最大呼気流量の 低下が推測される。今後農村の集団検診にこの方法を 取入れるべきことを提唱された。

18 では, い草労働従事者およびハウス園芸従事者を 対象として肺機能検查を行い, (1)肺換気機能は加令と 共に低下し，男女差も著明であり，い草地区は八ウス 地区に比して低下しており，(2)肺活量と一秒率と の相関が強く, 男女とも最大呼出速度と PFR との相 関が強いことを統計的に示され，(3)呼吸器症状有症者 と肺機能検查成績不良群との関係について言及した。

19 では, 農村における慢性呼吸器疾患に対する健康 管理の足がかりとして, 静岡県の山村佐久間町山香診 療所の外来患者の中から肺結核, 慢性気管支炎, 気管 支喘息について集計し，各疾患とも加令と共に增加し，
気管支喘息の主な抗原としてスギ花粉, ハウスダスト, カヤ・ツガの製材時の粉じんをあげてこれを重視して いる。

20 では, 前題につづき, かつて同地区の鉱山で労動 していた者につき，じん肺症およびこれに伴う肺結核， 慢性気管支炎等の実態を報告し, 鉱山労働者以外の珪 肺あるいは炭焼夫のじん肺についても症例をあげて論 述したが，現況としては労災の管理 3 以下の者につい ては公費治療が行えないことに問題を提起した。

21 では, 農村における花粉症のうち, オーチャード グラス, イネ, キク等 3 種の花粉症の大要を報告され, (1)オーチャードグラス花粉症についての皮ふ反応検査 では, 対象 58 名中 12 名に陽性, 9名は明らかに花粉 症と診断された。(2) 亿亦花粉症では, 外来患者中 15名 にその症状があり，8月がその好発期である。(3)キク 花粉症では外来患者のアレルギー性鼻炎の $37.5 \%$, 全 気管支喘息の $12.5 \%$ にキク花粉症反応が陽性であり, 6 月から 11 月に好発すると報告された。 
$588(38)$

22 では, 10 年間に発生した 42 例の特発性気胸につ いて検討し，(1)近年とくに増加してはいない。(2)とく に多発する年令層はない。(3)弱年者には肺に肉眼的基 礎疾患を見ない孤立性気囊胞の破裂によるもの，高年 令者では, 肺の広範性気腫変化を基盤として起ったも のが多いことを報告し，さらに従来の報告と比べて都 市と農村では発生年令層に相違があると述べ，今後と も農村におけるこの方面の研究の必要性を強調された。

質問は19·20に対してのみ行われたが, 浅川(茨城・ 水戸)は, 23 名のじん肺管理 4 は結核合併のためか心 肺機能低下のためかと質問し，演者は後者によるもの が圧倒的に多いと答えた。また神戸(長野・佐久)は, 真菌類のアレルゲン検査は行ったかと質問し, 演者は, 真菌類の陽性者はあまり見られなかったと答えたが, 神戸はさらに, 皮内反応をすると陽性率が高いのでそ れを試みられるよう希望した。次の質問者(氏名不詳)
は，秋田県では，アメリカ杉の粉じんによるアレルギー が多いが, 19 の場合は如何と質問し，演者は，この場 合は製材労働者を対象としたものでないから米杉の陽 性者はなかったと答えた。最後に高松(久留米大)の, じん肺では管理 4 のみか管理 3 以下にも医療保障が必 要と思うが如何という意見に，演者も全く同感である と述べた。

以上のごとく, 農村における呼吸器疾患は, (1)従来 の農業労働に加えて, 出稼ぎ, 通勤, 工場労働等, 都 市化した兼業態勢にある農民の労働自体によるものや， (2)農山村の生活環境そのものからくるものや，(3)一般 的な老令化に起因するものなど，種々の要因をはらみ つつその数は増加するであろう。これは医療上, 社会 福祉上:今後ますます重視されねばならぬものであり， 農村医学会の課題でもあると考える。

\section{医 功 物}

23. 恙虫病の経験例——特に新潟県内発生の疫学的考察

24. 長野県におけるワイル病について

新潟県 中央綜合病院 古田島昭五 - 他 2 名

長野県 佐久総合病院 大島紀玖夫・他 5 名

座長 鳥取大学医学部教授 加茂甫

23 は, 発熱, 淋巴節腫大, 皮虚潰瘍（症例 I は陰粪 部, 症例 II は大腿部）の典型的な主症状を示した，長 岡市内信濃川中洲に遊んで後約 1 週間で発症した 2 例 の恙蜹 (それぞれ19才, 9才の男子) について, 詳 細な経過を報告した。初診の医師の診断が風邪であっ た事でも知られるとおり，患者家族を含めて当地方住 民の間で，本症に対する警戒心はおろか初歩的知識す ら失われていた実情が, 発熱の繰返し, 経過の遷延と いう結果を招いたという警告である。そして，恙虫病 について概説し聴衆の記憶を喚起するとともに, 新潟 県の 1940 1973 年の記録をまとめ, 統計上は 1950 年 をピークに患者発生が漸減して 1965 年にはほとんど見 られなくなり, 戦前あれほど高かった致命率も化学療 法の発達で 1952 年以降死亡例 0 となり, 長岡市周辺
では絶滅病といわれるほどになったが，長岡保健所の 記録では患者発生が細々ながら続いていたことを思わ せるものがあったなどのことを明らかにした。

恙虫病は, 病原体発見をはじめ, その複雑な伝播様 式，病理などに関する知見がわが国の学者の努力によ って明らかにされたもので, 古典的恙虫病と呼ばれる 夏型流行の他に, 日本各地には冬型の異型（致命率は 低い）が存在することも知られており，農村医学の中 で, 忘れてはならない疾患の1つである。自然発生地 （natural foci）の病原をめぐる複雑な生態系に対する 系統的持続的な研究と対策の必要性を指摘された重要 なご報告である。

24 は, 従来長野県には稀とされていたワイル病がか なり広汎に存在し, 流行形態も風土病としての性格と 
は異なることに注目して，5年間の発生集計を報告す るとともに，その流行の特異性と発生要因および感染 機会について述べ, (1)1969 年より長野県下に発生して いる患者数は, 5 年間で 82 名, 内死亡者 15 名で, 農 業の男性に多い。(2)千曲川，さい川，さらに今年にな って天竜川沿いに点々と広い発生が見られ，ネズミの 保菌もそれに一致している。また患者発生のない地域 も既に污染されている。(3)この流行を生んでいる要因 にドブネズミの增加，移動が考えられるが, 1969 年以 前に既に各地に存在し多発の下地はつくられていたと 推測される。(4)ワイル病だけでなく秋疫 $\mathrm{B}, \mathrm{C}$ も存在 する。(5)感染機会は, 農業では稲刈前の水田の仕事は いずれも感染機会となるが, 特に養殖の仕事が危険で あり，非農では魚取りで感染する場合が多い。とまと めた。有馬(山口・周東) は, 山口県柳井市において 1973 年 1 月と 10 月に来院した, ワイル病 (44 寸主婦),
秋疫 B(44才男, 農業)の例を追加報告し，抗生物質の 普及と共に，不明のまま経過したり，見逃がされたり しているレプトスピラ症が周辺にあるのではないかと 警告された。

1972 年の国際農村医学会においても, 農業従事者の 職業病としての本症の重要さが, 各国の学者により指摘 されていたのを思い出すが, これまた農村医学の中で おき忘れがちな課題を指摘された重要な報告と思われ る。

柳沢(自治医大)も「例えば鹿児島離島のハブ対策の 如き問題も含めて，なぜ今日対策可能な疾病が，この 2つの報告のようにまだ撲滅されていないのか。行政当 局の姿勢に問題はないか。国民の健康に対するニード は非常に高度になっている今日，まだ恙虫病の発症が あるとは考虑すべき現象である」と極めて重大な意見 を述べられた。

\section{䋤薬と健康 I（中毒の実態調査）}

25. 埼玉県内における農薬使用現況

·埼玉県 幸手病院 山

優

26. 農薬散布従事者の農薬散布と健康の関連について

千葉大・農医研 石 毛 忠 雄 $\cdot$ 他 2 名

27. 三重県上野市羽根地区梨園農家の農薬污染について

$$
\text { 三重県 中勢総合病院 西川健 } \cdot \text { 他 } 9 \text { 名 }
$$

28. りんご園における農薬散布 S.S. オペレーターの長期健康追跡調査結果に関する

$$
\text { 検討………………………長野県 北信総合病院 永田否・他11名 }
$$

29. 塩素酸系およびジクロルプロピオン酸系農薬による皮膚障害

$$
\text { 熊大医・公衛 松下 敏 夫・他 } 4 \text { 名 }
$$

30. 菊栽培農民に対する農薬と菊の葉エキスのパッチテストの調査報告

日本農村医学研究所 神 辺

譲

座長 岩手県立山田病院長 高 野 喜 正 熊本大学医学部助教授 松下 敏 夫

25 は，演者も説明している如く，この地区の農薬使 用状況としての基礎的調査であったが，その農薬の種 類が 300 種にものぼることにより, 当然, 各種農薬による 農薬障害の発生が心配される所である。この報告をも
とに今後更に掘り下げた調査を期待する。2 26 は, 広範 囲な地区について詳細にわたって調査されたのである が，その御苦労に敬意を表したい。これによって吾々 は, 農薬には如何に混合剤が多いか, あるいはまた農 
薬散布回数が多いかを再認識させられた。然しながら 演者もいわれる如く, 健康異常出現において高散布群 と低散布群との比較においてはあまり著しい差はなく, かつ検査上著変がなかったようであるが，これらの中 から今後潜伏性農薬障害, あるいは慢性中毒化しない とはいえないので，今後更に長期にわたっての調査を 期待したい。27は, 詳細な調査形式で, 農繁期と農閑期 との成績を比較し, 毛髮水銀量定量または各農薬散布者 の発症状況，あるいは土壌中の残留農薬の測定によっ て䀼薬污染状況を調查されたのであるが，トランスア ミナーゼ上昇, あるいはコリンエステラーゼ軽度上昇 が農繁期に多いことは, 今後慢性中毒の関連について 興味深いことである。然し, 内田(千大・農医研)発言 の如く，男性と女性は，作業内容ならびに体質的にも 格差があると思われるので, 今後は性別を明示されれ ば幸いである。28は，SS オペレーターの健康管理に ついて, 毎年本学会に報告されている所であり, 本年 は 40 年と 48 年との成績の比較を報告された。 48 年の 方が有症状者率またはコリンエステラーゼ低下者が激減 したことは，農薬の規制，あるいは低毒化により当然 とはいいながら，今昔の感を強くした。然し一方農薬 長期散布による $\mathrm{ChE}$ 高度低下者は, 慢性肝障害として 今後の調查が興味深い。また, 演者は新しい問題とし て, 大型 SS オペレーターの後継者難のために小型 SS に切りかえられつつあり，多戍農薬を使用することで 取扱いが雑になり, 健康管理上逆行するのではないか とのことである。今後充分注意しなければならぬこと と思う。

以上 4 題は, 農薬障害の実態調査であるが, ここで 農薬障害の実態調査のアプローチに関しての貴重な発 言を記しておく。

-内田(千大・農医研)は, 1 ) 農薬急性中毒の場合は アンケートの制約を考虑しなければならぬが，実態調 査を通してかなり明瞭に出来ると思う。 2 ) 慢性的異
常については，(1)集団に対する疫学的検討が必要であ る。農薬そのものによって, 長期にわたってどの位影 響をうけているか。農薬散布の実態と健康異常につい て性別, 年代別に詳細に, かつ継続的に調査する必要 があろう。(2)臨床的症例のつみかさねが大切である。 と述べ,

若月 (長野・佐久)は，急性中毒についていえば，農 薬をまいて具合が悪くなったということだが，夏の暑 いときは農薬をまかなくても具合が悪くなるのだから これを農薬によるものだと断定することは“ずさん” のみならず，“まずい”と最初からいわれてきたが, これをあえてしてきた。それは，これを含めないと， 本当の実態をつかめないからである。

農民の訴えとして“農薬散布に従事したらこんなに なった”という言葉を信じて，その実態を調べること の重要性を忘れてはならぬと思う。客観的所見がない からといって，それによる諸症状(ことに不定の)を抹 殺しては, こういう問題の追求は出来ないと思う。

29 は, 除草郕は有機燐郕と共に農薬中最も使用量の 多いもので, 農薬散布従事者への影響力も大きいわけ であるが，これによる皮虚障害も年々增加の傾向にあ る。ここにおいて，演者はこれによる接触性皮虙炎の 原因を，動物実験も加えて解明しようとしたのである が，除草戍による一定の刺戟反応は認められたとのこ とで, 今後の研究の成果を期待したい。

30 は，数年にわたり農薬の接触性皮虚炎とアレルギー に関しての研究報告をされてきた。今回も又, 各種農 薬のパッチテストによる調査報告をされたが, 対照群 との差が明らかであり，ますます，接触性皮膚炎とア レルギーとの因果関係について自信を深めたことと思 う。菊の葉抗原によるパッチテストは, 反応が弱いと のことであるが, 野村(熊大・公衛)の発言の如く, 出 来たら菊の葉そのものによるパッチテストも行なって いただきたい。 


\section{裳菜と健䐂ＩI（中毒の臨床）}

31. 農薬中毒臨床例全国調查（昭和 48 年度報告）

$$
\text { 日本農村医学会・農薬中毒研究班 菅 谷彪・他 }
$$

32. 県内に発生した農薬中毒について……静岡県衛生部薬務課 石川静磨・他 2 名

33. 有機燐郕「カヤホス」による急性中毒多発について

愛媛県立北宇和病院 岡 田 尚 久.他 3 名

34. 除草戍パラコート（グラモキンン @）による急性中毒の 1 治験例

福島県 藤田総合病院 佐 藤二 郎 - 他 2 名

35. 有機フッ素系農薬 N-メチル-N-1-ナフチルーフルオロ-酿酸アミド (ニッソール)

の毒性と解毒剈について 阪大理学 中南元・他 2 名

座長 徳島県 麻植協同病院副院長 坂 東 玲 芳 長野県 佐久総合病院外科医長 船 崎 善 三 郎

31 は日本農村医学会・農薬中毒研究班を代表して, 昭和 48 年度の症例を中心に 3 年間の調査結果をまとめ て報告した。これは全国の主な農村病院 50 機関を訪れ た農薬中毒患者 551 例についての集計である。

この調査結果のほかに, 秋田県公害課で行ったアン ケート調査の結果などをあわせ報告し, 農薬中毒に対 する関心が高まっているにもかかわらず症例は必ずし も隇っていないと指摘し, 特に低毒性農薬でも急性中 毒をおこしていること，また多戍併用に注意が必要で あると述べた。臼谷(弘大・公衛)から有機燐剤の慢性 中毒の症例及びその診断基準について質問があったが, 菅谷は，症例はこの集計では慢性中毒の疑としてその 他の項に入れてあり，今後，臨床家がつかえるような 診断基準をみんなで考えてゆく必要があると述べた。

32 は, 最近 20 年間に静岡県に発生した農薬中毒事故 （保健所を通じて県衛生部に報告されたもの）について 検討を加えた。

全症例 1,130 例中 854 例 (76\%) は自殺のための事故 であり,この数は 20 年を通じて殆ど減少していない。 最近でも毎年 40 例前後の事故があり, 危害防止のため の努力, 低毒性農薬開発の必要を訴えた。

33 は, 新有機燐戍「カヤホス」散布による急性中毒 9 例について報告, 新農薬採用にあたり，その毒性の 充分な検討と, 使用上の注意を充分宣伝する必要があ ると述べた。高野(岩手・山田病院)の服装防備は完全 にして作業したというのに，中毒の原因は何と思われ るかとの問に, 兼業が多く勤務終了後の短時間に多量 に(普通の倍量)使用したのが原因であると思われると
の答があった。菅谷(秋田・平鹿病院)より，農薬中毒 臨床例の原因調査では, 防備不充分と思われるもの 40 $\%$ ，薬戍に問題ありと思われるもの $20 \%$, 健康状態の 不良だったもの $18 \%$ となっており, 薬侴の併用, 使い 方等がかなり問題になるのではないかとの追加があっ た。

34 は自殺の目的で飲用した, グラモキンンの急性中 毒患者を強制利尿とステロイド療法にて救命した一例 を報告した。

松島 (長野・佐久病院)は本症によく併発する肺線維 症の合併の有無についてたずねたが，その合併はなく， 恐らく早期からのステロイドの使用が奏効したのでは ないかと答えた。

- 35 はニッソールの毒性とこの中毒の際の特効薬とい われるアセトアミドの解毒作用について文献的考察を 加え，ニッソールのように毒性が動物種差の大きいも の, 経皮毒性のつよいものは広く散布させるには適さ ないと述べ，また，アセトアミドもその作用機序から して早期( 1 時間以内)に使用されるのでなければ効果 は少ないのではないかと述べた。上田(東歯大・衛生) は, ニッソールが劇薬として扱われている点, また医 薬品でないアセトアミドが特効薬といわれている問題 などに対し，使用者はもっと強く政府に圧力をかける べきだと述べた。

以上農薬中毒のうち特に急性中毒の臨床的な問題が 報告されたが，その発生状況は，アンケート調査でも 臨床例調查でも, 保健所への届出数でも減少の傾向が 少いことが指摘されよう。中毒の内容は皮虐障害が多 
くなるなど若干の違いはあるが，低毒性といわれるも のでも障害がおこり, 特に, 大量に用いること, 頻回 に用いること, 混合剤の使用などで思わざる重篤な障 害もみられる。農薬による自殺も減少していないのは やはりまだ管理の面での注意が必要なのではなかろう か。グラモキンンの中毒は厚生省薬事課の集計でも, 昭和 46 年の 50 例の中毒事故のうち救命しえたものは
僅か 3 例という報告があり，この種の農薬の使用，管 理上の注意とともに, 救命し得た症例の報告は, われ われを力ずけるものがある。目に見える急性中毒には 対応する方策は何とかみつけることが出来るであろう が, 潜行する慢性中毒, 複合污染, 催奇形性, 発癌性 など, 農薬をめぐる問題はこれからだという感がふか い。

農薬と健康 III（有機塩素系残留）

95. 人体に於ける残留有機塩素量一一昭和 48 年度報告一

秋田県 平鹿総合病院 鈴 木 保 男 ·他 4 名

96. 有機塩素郕の人体内残留に関する研究 (第 5 報)

97. 有機塩素系農薬の人体臓器残留について

日本農村医学研究所 河 西朗 - 他 2 名

千葉大・農医研 高 宮 恒 治・他 1 名

98. 農村主婦の血液中, 母乳中の有機塩素系農薬の残留量について

久留米大・環衛 井 上 義 人・他 2 名

99. 八ウス農業における残留農薬の研究，(第 1 報) 土壤及び生体内分布と蓄積量の経

時的変化と生化学的変化……重県 中勢総合病院 鈴 木 宏 幸・他 2 名

座長 秋田県 平鹿総合病院副院長 菅谷彪 青森県 工藤内科病院長 、工藤 尚義

95 から 99 まで 5 題は, いずれも有機塩素系郕の残

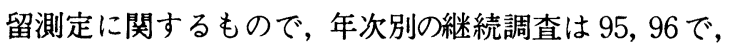
臟器内残留に関する測定調査は $95,96,97$ の 3 題であ つた。98は, 血液と母乳中の量に関するもの, 99 は, 八ウス内のラットにおける実験研究であった。

まず，95は，継続的な成績を報告し，母乳では $\alpha-$ $\mathrm{BHC}, \gamma-\mathrm{BHC}$ の著しい減少, $\beta-\mathrm{BHC}$ の比較的増加 を示した。とくに初産と経産の total BHCでは, 初産 $3,880 \mathrm{ppm}$, 経産 1,223 ppm と報告した。年次別には, 脂肪組織の $\beta-\mathrm{BHC}$ は前年より降下の傾向を示した。 癌・非癌の脂肪組織では, total BHC は, 癌 $1,728 \mathrm{ppm}$, 非癌 $2,245 \mathrm{ppm}$ で癌患者が少ないが， $\alpha-\mathrm{BHC} に つ い$ ては癌患者の方が高值であった。total DDTは, 癌 $1,368 \mathrm{ppm}$, 非癌 $2,320 \mathrm{ppm}$ である。臓器では脳, 脾, 肝, 腎, の順に高值になっていた。
96 は, 脂肪組織および蔵器について報告した。全検 体から， $\beta-\mathrm{BHC}, \mathrm{pp}^{\prime}-\mathrm{DDE}, \mathrm{pp} \mathrm{p}^{\prime}-\mathrm{DDT}$ を検出し, 男性および高令者に残留量が多いと述べ，9才以下の 3 例の高值は, 母乳および牛乳の飲量の多いことが理 由と推定している。癌・腫瘍群ではいずれの有機塩素 も多く, 年次的には, total BHCは 49 年より, total DDT 48 年より增加傾向にあると報告した。

97 は, 蔵器の残留測定結果では, $\beta-\mathrm{BHC}$ おび $\mathrm{pp}^{\prime}-\mathrm{DDE}$ が各蔵器に多く, 60 才代の男 3 例では腸間 膜, 副腎, 肝臟, 宰丸の順序で小さい值になっていた。 また，蓨髄は腸間膜の 40 ～50\% の割合に残留してい た。 $\mathrm{pp}$ '-DDD は腸間膜では $100 \%$ ，ほかにへプタク ロール， op'-DDTなどもみられた。

98 は，母乳と血液中の残留量を測定し， $\beta-\mathrm{BHC}$ は 母乳中で $98.6 \%$ も占めていることを報告し， $\beta-\mathrm{BHC}$ 
と $\mathrm{pp}^{\prime}-\mathrm{DDT}$ は母乳と血液との間で高い相関があると した。また，母乳中(脂肪換算)量の血液中量に対する 割合は, $\beta$-BHC で平均 1,250 倍, $\mathrm{pp}^{\prime}-\mathrm{DDT}$ で 430 倍, $\mathrm{pp}^{\prime}-\mathrm{DDE}$ で 400 倍, PCB で 250 倍であると述べた。

99 は, 八ウス農業の生体影響を研究するために, ウ イスター系のラットを用いて, 農薬の暴露実験を行な

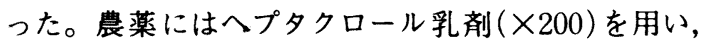
$45 \mathrm{ml}$ を週に 4 日間, 1 日 4 回散布し, 体重増加, 血液 および生化学検査, 臟器残留を調べたところ, 八ウス 群と一般群との有意の差は, 体重の増加率の減少にあ った。ほかに特に大きな差異はなく, 臓器では腎に多 く残留していた。

また，若干の赤血球数の減少などから，農薬による 健康障害は考えられると結んだ。

上田：96の表 3 のうち, 皮下脂肪と腸間膜の total DDT の平均濃度に大差がある理由は何か。皮下脂肪 に異常高值があるためか。癌患者に残留が多い傾向が あるというが, マイアミ大学では, 動脈硬化, 高血圧 症でも同じ程度の貯留を認めているので, この種の脂 肪代謝異常疾患も対象に入れてほしい。96，97，98に 対し, 腸間膜を選ぶのはどういう意味か, 脂肪組織と いう意味なら脂肪重量単位の発表も必要であろう。

河西：皮下脂肪，腸間膜の残留平均値に大差がある のは，表 3 の平均誤差の点を考えても，これらのもの が偏差が大きいためだと考える。癌および腫瘍患者が 多い点については, 第21 回当学会の発表データでも, 統計的に有意をもって平均值に差が出ていた。腸間膜 が取りやすいから用いている。脂肪組織としてではな く, 抽出された体脂肪として測定しているので, 臓器 による差は少ないと考える。この報告にあるものは臓 器分布によるもの以外はすべて体脂肪として測定して いる。

上田：癌に多いと思うが，ほかの疾患にも多いと
いうから，ほかの疾患も対象とすべきである。脂肪量 で表わさないと国際的比較も国内比較も出来ない。腸 間膜で測るのなら脂肪含有量も測定することである。 河西： 4 年間のデータは, 体脂肪含量の形で測定し ている。

上田：98に対して，血液は血漿のようだから，そ う書かないと誤解される。また，表の下の下段母乳は 脂肪単位と書かないといけない。PCB 一一緒に測る のは良い。塩素郕は肝臓に共同作用があるから, 農村 医学会だからといって農薬だけしか測らないのは医学 的評価は出来ない。福島の公衆衛生学会で, 東京都の 衛検が, 血液, 脂肪中の未知のピークをガスマスで確 めたら, パラクロールベンゼン(防臭, 防虫郕)が多量 に認められた。水洗便所のない農村では多量に用いて いるかも知れない。従って, 農村医学会だから農薬だ けでいいということにはならない。

井上：母乳は脂肪換算である。大網についてもファ ットベースとトータルベースで発表している。母乳で は差がなかったが, 血液と大網では, ファットベース では相関したのに, 大網全体換算では相関しない経験 がある。

菅谷(座長)：残留が慢性障害につながるかどうかに ついては，未だ充分な検索はなされていない。残留量 についても, 地域差, 年度差が考えられる。農薬だけ というのでなくという上田先生の指摘は，そのとおり だとは考える。

継続している調查はもちろん, 血液と母乳の関係な どは他の地域でも行なってほしい。ハウス農業につい ては更に研究を重ねてもらいたい。

工藤 (座長)：血漿の有機塩素排除に如何なる方法が あるのか, 癌患者に有機塩素が多いというが, 予後と の間に関係あるかどうか，この点について将来教えて もらいたい。 
100. 共同防除作業における農薬被曝量と血中有機燐農薬の動態 弘前大・公衛 西 山 邦 隆・他 2 名

101. 農薬中毒の病態生理一一全血中有機燐をめぐる $2-3$ の検討（16報） 青森県 工藤内科 工 藤 '尚 義

*102. いわゆる慢性有機燐中毒に関する調査成績 弘前大・眼科 松 山秀一・他 3 名

103. 関東地方農村地区学童視機能の集団検診 自治医大 $\cdot$ 眼科 内 藤 誠 $\cdot$ 他 3 名

104. 毛髮中の水銀化合物の分析

日本農村医学研究所 中 村 俊 - 他 9 名

105. 農薬散布による野菜中重金属及びビタミン Cへの影響（第 2 報）

日本農村医学研究所 広岡 佑三郎・他 9 名

$\begin{array}{clllll}\text { 座長 長野県 佐久総合病院健康管理部長 } & \text { 松 } & \text { 島 } & \text { 松 } & \text { 翠 } \\ \text { 東京歯科大学講師 } & \text { 河 } & \text { 合 } & \text { 正 } & \text { 計 }\end{array}$

この群では，有機燐の人体内残留，慢性有機燐中毒 一とくに眼障害との関連，水銀の残留等の問題がとり あげられた。

100，101では，いずれも血中有機燐の残留について 報告があった。西山によると，SS および定置配管 式による散布で，散布者の吸気中濃度は，SS 0.0112 $\mathrm{mg} / \mathrm{m}^{3}$, 定置配管 $0.0356 \mathrm{mg} / \mathrm{m}^{3}$ で，後者の方がやや高 かったという。また血清中有機燐は, 散布直後にいず れも $0.03 \sim 0.06 \mu \mathrm{g} / \mathrm{ml}$ 程度の残留が認められたが, 36 時間後には全員不検出か痕跡であった。別に散布終了 後数ケ月後にも調べたが，有機燐は検出できなかった という。

工藤は，リンゴ専業地帯の農民と都会居住者につい て，散布作業と関係ない時期に，全血中の有機燐を分 析した。それによると，メチルパラチオン $0.032 \sim 0.340$ ppm，サリチオン $0.017 \sim 0.055$ ppm，エカチン 0.008 $0.810 \mathrm{ppm}$ 検出したという。散布と関係ない時期に検 出し得た理由として, 工藤は, 農閑期の農薬使用, 飲 料水，食品からの摂取が考えられると述べたが，それ にしてはオーダーがあまりにも大きく，果して $2,3 の$ 会員から，分析技術に問題があるのではないかという 意見が出された。

すなわち, 臼谷(弘大・公衛)は, 昨年の本学会で, 生体中の有機燐の同定方法についていくつかの意見(例
えばカラムを変える，ガスマス使用など）が出された が，これらが充分考虑されたかどうか，もし考虑され ていないとすれば，それを確立したあとで，侵入経路 その他について考虑すべきであり，まず同定方法の確 立が先決であると述べた。

また杉本(日本農薬)は，工藤のいう unknown peak について計算の仕方にいろいろ疑問点があり，GC-MS 等の技術を使って，分析技術を確立する必要があろう と述べた。

また，上田(東歯大・衛生)は，自分も全血を試料と しているが，妨害ピークが多数認められ，それらは溶 凨, 滤紙, 無水硫酸ソーダ等からくるので, 試薬精製 が第 1 段階である。工藤のいうサリチオンらしいピー クも，力ラム充填剤をかえると移動するので，疑ピー クである。微量定量はその方法を明示し，研究者が同 一試料を分析して相互のクロスチェックをすることが 必要である。もちろん GC-MCによる分子量測定も必 要であると述べた。

以上，いくつかの意見交換からみて，工藤のデータ は，分析技術上大きな問題があると思われるので，そ れをこのまま信用するわけにはいかないであろう。分 析方法の確立が先決であるが，それとともに学会内部 でクロスチェックを行なって，お互いの方法を検討す る必要がある。 
102 は, 紙上発表であったが, 従来いわれている慢 性有機燐中毒一とくに眼障害の有無について, リンゴ 栽培農民について検診を行なっているが, 少なくとも 石川氏(北里大)の報告しているような高頻度の異常者 はみつからなかったという。

103 でも, 農村地帯の学童の視機能の実態を把握す るため, その集団検診を行なっているが, 視力, 視野 に関しては非常に良好だが, 瞳孔運動にかなり abnormal の例をみている。その原因として, 検査当時の農薬(有 機燐)の散布も考えられると述べた。また演者は，農薬 眼病として問題になった佐久, 守口の眼科検診も行な つた経験があるが，それとのちがいについて，佐久，守 口の検診では, 病院受診患者のうち, 原因不明の視力 障害患者を主体として，その兄弟・家族が主体であっ たが，利根川地区では，小学校 6 年生全員およびその 父兄が対象であるので，対象が異なり，障害児が少な いのはそのためであろうと述べた。

营谷(秋田・平鹿)は，以上のような結果からみて， 学校検診で視力, 視野をみることはあまり意味がない のかと質問したが，内藤は，そうとはいえないが，た だ瞳孔系, 眼球運動系の試験は非常に敏感な検査であ るので, 視力, 視野の検査で異常があらわれない程度 の軽い異常を発見し得るという意味では重要であると 述べた。

有機燐による慢性中毒としての眼障害の有無につい ては，石川氏の発表以来大きな問題になっており，動 物実験も数々行なわれている。有機燐が ChE 活性値 を阻害し，神経系とくに運動終板に変化をあたえるこ とは今まで本学会でも発表があった。したがって, 眼 にも当然変化がきてもよいわけであるが，動物実験で
惹起した病像と, 学童の眼の異常とが完全に一致する かという点になると, まだ疑問点も多い。有機燐が今 後多く使用されるだけに, 今後検診を各地で継続され 実体を解明されることを望みたい。

104 は, 人体毛髮中の水銀化合物の測定結果が報告 されているが, 総水銀量は, 非農男子 $4.82 \mathrm{ppm}$, 農業 男子 $3.30 \mathrm{ppm}$, 非農女子 $3.05 \mathrm{ppm}$, 農業女子 $1.64 \mathrm{ppm}$ で, その中メチル水銀含有量は $52 \sim 64 \%$ である。一般 に非農が農にくらべて多く，また，男子が女子にくら ベて多いが，これはとくに食生活(魚の多食)の影響が 多いと述べている。

上田(東歯大)は, 分析法に関して, 水銀分析法は年 次的に比色法, 湿性灰化, $\mathrm{O}_{2}$-ボシべ法, 直接燃焼と 種々の方法を経てきて，分析值もこの影響をこうむつ ている。したがって分析値の時代的比較には, 前の時 期の試料の一部を現在の分析法でチェックする必要が あると述べた。この意見は, 他の農薬の分析にもあて はまるので, 今後継年的に種々な農薬を分析していく 場合注意すべきことと思われる。

105 では, 実験的に栽培し; 農薬を散布した野菜(レ タス)中の重金属とビタミンCの量を測定しているが, ビタミン C は無農薬栽培がもっとも多く, 農薬散布し ているものはそれに対して約 $20 \%$ 減になると述べてい る。また, 八ウス栽培は露地栽培にくらべて少ない傾 向がある。しかし, 鉄の含有量については, 農薬栽培 と無農薬栽培とではあまり差がない。農薬を散布する と, ビタミン C や重金属が減少するということは, ソ ヴィエトの Antonovitch らの研究があるが, これは栄養 学的にみても重大な問題であるので, 今後充分追究し ていく必要があると思われる。 


\section{農薬と健康 V（動物実験）}

106. 有機燐農薬の生体内残留に関する実験的研究

弘前大・薬理 高 橋·政 教・他 3 名

107. 有機燐剤の生体内残留に関する実験的研究（第 3 報）

日本農村医学研究所 浅 沼 信 治 ·他 6 名

108. 有機燐農薬の中枢神経への影響に関する研究, (第 3 報) 各種農薬の反応様式の相

$$
\text { 異について………………... 日本農村医学研究所 堀 口佳 男・他 } 1 \text { 名 }
$$

109. スミチオンによる組織変化の電顕的研究

日本農村医学研究所 鈴木彰・他 7 名

座長 東京歯科大学教授 上 田喜 一

106 は, 家兔をモデルビニルハウスに入れ，スミチ オンまたはサリチオンを 1 日 5 時間， 3 日間噴第暴露 させた後の血液中有機燐の消長は 24 時間後急激に減 少し， 3 日後はガスクロの検出限界以下に消失した。 また，四塩化炭素で肝障害を起させた家兔でも，血中 有機燐の消長には対照群と比較して差を認めなかった が ChEの回復が遅れることを見出した(追加資料配布)。

菅谷(秋田・平鹿)の肝障害者は農薬中毒に弱いとい う医学常識に矛盾する成績と思うがという問に対し， 血中有機燐の消失過程には差がなかったが $\mathrm{ChE}$ の回復 が遅れる点で矛盾してはいない, $\mathrm{CCl}_{4}$ 量をこれ以上増 加すると動物は肝障害のため死亡するので実験困難で あると答えた。

上田は，抄録中に「体表面を被覆して経口的吸収に 限定した」とある点はこの種の実験は吸入が取り込み の主経路であるから，この表現は訂正する必要がある ことを指摘した。

107 浅沼ら (日本農村医研)は, アカゲザル一群 5 匹 を用いて比較的少量のスミチオン $(2 \mathrm{mg} / \mathrm{kg})$ をバナナ に注入して投与したが, 血中スミチオンは 9 時間ない し1 日で最高ピークに達し，3 日後には急減，5 日後 は 1 例を除き全例検出不能となり, 尿中パラニトロ・ メタクレゾールも 1 ～ 2 日で投与量の大部分が排泄し 終る。血漿 $\mathrm{ChE}$ は $-30 \%$, 血球 $\mathrm{ChE}$ は $-10 \%$ で回 復には 3 週を要した。

抄録以外の追加資料として農薬散布者の血中有機燐 分析が報告された。S.S. スプレーヤーを中心に動力散 布従事者を含めて 22 名から有機燐散布後 $7 \sim 10$ 日目 に $6 \sim 7 \mathrm{ml}$ を採血( 49 年 8 月), 血中に有機燐(スミチ
オン, マラソン, パラチオン, ダイアジノン, DDVP, サリチオン)は検出されなかった。また冬期(47 年 2 月) に農薬散布と関係のない病院勤務者の血液からも有機 燐は検出できなかった。したがって有機燐が長期間体 内に在留するおそれはないと結論した。

菅谷氏の「食品としての農作物も影響がないという 意味か」との問に対し, 仮に $1 \mathrm{ppm}$ の野菜 $1 \mathrm{~kg}$ をたべ ても有機燐 $1 \mathrm{mg}$ の捸取で, これは $0.017 \sim 0.2 \mathrm{mg} / \mathrm{kg} に$ 過ぎず，その影響は短時間に消えると思われると答え た。

石川ら(北里大眼科)の称える有機燐による眼の屈折異 常, それに伴う血中多種の有機燐農薬長期残留説に対 してはすでに昨年の本学会で反対討論が多数提出され たが, 本年は動物実験および動力散布作業後でもせい ぜい $2 \sim 3$ 日の血中残留である成績が 2 題提出された。

上田も，ビーグル犬にスミチオンを連日投与しても 血中濃度は極めて低く検出限度に近いレベルに過ぎず, 一般住民の血液に見られるガスクロ上のピークは有機 燐でない疑波であって, 北里大のようなアセトン抽出 では沪紙，硫酸ソーダなどの試薬からも FPDに感じ る疑ピークが出てくることを追加した。

浅沼が指摘したように，血中有機燐測定には現在の 北里大学法は再現性がなく, 早急に統一的方法を協定 する必要があることを研究者一同痛感し，昼休みの時 間に関係者一同が集まり若月理事長を班長として研究 班を発足さすことを一同申し合せ，農村医学会事務局 に事務的処理を依頼した。

108 は, 家兔に相当多量の有機燐を静注した場合の 脳波, 心電困の観察であるが, マラチオン, スミチオ 
ンでは軽度徐波の後に突発性棘波が出現するのに反し， DDVP，バミドチオンでは觉醒波が持続し異常波は出 現せず，投与量を多くすればそのまま脳死を来す。こ の差は前者群が $\mathrm{P}=\mathrm{S}$ 型であり, 後者群は $\mathrm{P}=\mathrm{O}$ 型の 有機燐であるためと説明した。

上田は $\mathrm{P}=0$ 型でも痙挲の強く現われる TEPP な ど有機燐の種類をさらに拡げて検討するよう希望した。

109 は，昨年のウサギ，サルへの少量投与の実験の 継続で, 本年はラットに $300 \mathrm{mg} / \mathrm{kg}$ の相当大量を 1 回投 与した実験である。血中残存スミチオンは 5 日までに 排泄されたが, 外眼筋の神経終板は 5 日以後に变化が 增強し synaptic vesicle に空胞化などの変性が現われ, 30 日で複雑多彩な修復像が見られた。すなわち不可逆 性変化ではないが, 慢性的あるいは後遺症としての神
経機能障害がありうることを示した。

上田から, 近来各地で工業用有機溶媒(ノルマルへキ サン，メチルイソブチルケトンなど)による末梢神経麻 㾝が報告されているので，これらでも syn-ves.の変性 が現われないか, この変化が有機燐に特有なのかを追 及して欲しいと希望した。

最後に上田から, $\mathrm{ChE}$ の測定は $\triangle \mathrm{pH}$ 法時代からア セチルチオコリン比色法に転換しつつあり, 䣼素活性 は基質の分解率 $\mu \mathrm{mol} / \mathrm{ml} / \mathrm{min}$ で表わ卞国際的表現法が 採用できる方法が望ましい。 $\triangle \mathrm{pH}$ 法は緩衝液の力が同 一処方で調製してもその時の試薬により一定でない欠 点があり，ことにヒトの血液用処方であるから動物組 織ホモジネートに応用すると緩衝能が異って来るので 相互比較が困難である欠点を指摘した。

\section{健 康 調 查}

36. 農業の変化に伴う農民の新たな健康障害に関する研究（第 1 報）一一農村病院

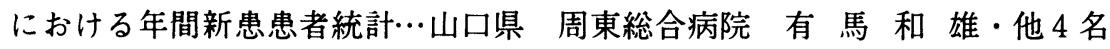

37. 秋田県における地帯別にみた国保受診状況及び死亡率の検討

.秋田県 十文字町 西 成 辰 雄

*38. 社会条件の変化に伴う農村における医療需要の変貌に関する考察

自治医大・公衛 倉 科 周 介

39. 農村地区における住民の体格と脚伸力との関係について

日体大 ·健康教育 諸 富 嘉 男 ·他 3 名

40. 集団健康スクリーニングを進める上での諸問題

長野県 佐久総合病院小諸分院 依 田 発 夫・他 2 名

41. 環境污染地区農民の健康意識について

金沢大・医療技術短大部 河 野 保子・他 2 名

座長 長野県 北信総合病院長 永 田 丕 大分県 鶴見病院長城田健 夫

36 は, 北海道・東北・東山・中国・四国の代表的な 厚生連 5 病院の昭和 48 年 1 年間の 160,309 名の新患 患者統計を報告した。この種の統計は本学会が昭和 29 年 に全国 9 厚生連病院の協同で行なって以来 20 年ぶりで, 本研究はこの間におけるわが国農村, 農業の変貌に伴
う農民の疾病構造の変化を病院患者統計から把握せん と指向するものでその第 1 報である。疾病頻度順位は 呼吸器系, 消化器系, 神経・感覚器系の順で消化器系, 呼吸器系, 不虑の事故中毒は男性が高く性器, 新生物 は女性に高い。患者年令別は $0 \sim 9$ 才台 20 才台 30 才 
$598(48)$

台の順で，季節別患者数は農繁閑期の差がはっきりし ない。保険別は社保 $57 \%$ 国保 $37.5 \%$ で社保が意外に 高い。世帯業種も専農 $13.2 \%$ 兼農 $23.0 \%$ 非農 61.9 \%で非農が高い。疾患と農・非農の関係では神経・感 毟器系, 筋骨骼系, 結合織, 循環器系疾患, 新生物に おいて, 家庭が専農ならびに当人農業が主なものが非農 に比して多い。37は, 秋田県の全市町村を農林省統計 による農業地帯別に区分し山村(へき地)に焦点を合せ てこれに国保統計から国保受診状況，国保財政，主要 三大疾患 (脑血管, 心疾患, 悪性新生物)死亡率を対比 分析した。すなわち受診率は山村が都市(秋田市)その 他農業地帯に比して著しく低く，一件当り费用は逆に 山村がもっとも高い。これは山村の疾病の重症度が高 いことを示す。一方保険財政からみると受診率の低い 山村住民が都市とほぼ同額の保険税を負担しなくては ならず，しかも国保に対する国庫支出金は受診率が高 い都市優位に支給される。また住民 1 人当り保健施設 費は平地農村, 農山村, 山村はすべて都市にくらべて 多く支出しているなどの予盾を明らかにした。さらに 三大主要疾患死亡率は平地農村, 農山村, 山村すべて が都市に比しても全国平均に比しても高いことを示す。 へき地度の高い農村の受診率をたかめ健康水準を高め るためには医療機関の確立に対する徽底的な対策が必 要で, 形式的な巡回診察対策などでは解決できない問 題をはらんでおり，また農村に重点的に国庫支出が平 等に行なわれるよう財政的措置をこうじ保健対策を急 速に充実する必要があると述べた。

これらの発表につき，柳沢(自治医大)は日本農村医 学会として，このような社会医学的な問題をとり上げ てゆくことを要望し, 今日的課題として今後とも推進 して欲しいと発言した。永田より, 有馬の今回の疾病 分類法について質問があり，有馬より，厚生省 $\mathrm{D}$ 表に よったと回答があった。

39 は, 長寿者率の高认福岡県朝倉町と, 対照として 秋田県平鹿町の農業従事者について体格と脚伸力の測 定を行い脚伸力において, 朝倉町より平鹿町において 男女ともに各年令層においてすぐれていることを認め た。脚伸力と体格の関係は朝倉町男子において脚伸力 と体重に相関が認められたが, 他は一定の傾向が認め られなかった。脚力は年令とともに低下し特に 50 代か ら急速に低下する。老化は足からはじまる。生活様式 の変化に伴い脚をきたえることを忘れてはならず，そ れが老化予防に役立つと述べた。菅谷(平鹿病院)は, 20 年前平鹿地区において高松(久留米大)が測定したデ
一夕と今回を比較すると身長体重は各年令層とも多少 良くなったが，背筋力肺活量はかなり低下して農民の 体格の年代的变化を痛感すると追加した。

40 は, 長野県厚生連が 48 年から開始したオートアナ ライザー・コンピューターによる集団ヘルススクリー ニング活動を進めた経験のなかから農村にこれを普及 するにあたってはとくに人と人のつながりの重要であ ることを考え，三つの段階でのとり組みを述べた。まず 一つ一つ部落に入って, 健康診断の重要性を理解して もらう教育啓蒙活動であり，これを通じて医療従業員 自身の学習, 姿势づくりも得られる。次に検診が終る とそこで受診者と想談を行なって村民の考えを聞くこ とにより医療の一方交通をさける。第三に検診結果は 機械的に送りとどけるのではなく部落に全員集っても らって部落のデータを説明してから個人に手渡す。最 後に抱えている問題として農協が行う健康管理の仕事 と自治体の行なう検晾の統一化の問題で, いくつかの 自治体の予算に，このヘルススクリーニングを組み入 れることに成功したとのべた。城田は，ことに結果を手 渡すというきめのこまかいやり方がついゆるがせにし やすいことであるが，大変おもしろいことであると発 言。又検診後主治医との関係をどう指導するかとの質 問に，原則として第 2 次以後の検診または治療はその 人のかかりつけの医師に依頼すると回答があった。

41 は, 工場の排出フッソによる大気污染地域および 隣接地域における健康調査において，未受診率がそれ ぞれ $26.2 \%, 38.6 \%$ と高く, 未受診者を調査したとこ ろ前者では仕事が忙しい，家にいなかった，後者では どこも悪くない，というものが多く健康意識の低さを 指摘し，地域住民がこの公害に対して法廷斗争まで行 なったに拘らず健康意識が必ずしも平行しなかった一事 例として今後起り得る同様な問題のための一助として 経験を述べた。豊田(金沢大)は公害に対する農民の意 識と健康意識のずれを同じ町の別な公害事例について も感じさせられた点を追加した。

最後に本群のまとめの討論で豊田(金沢大)は有馬の 病院新患統計と 20 年前の統計と異なる点として患者数 に農繁・閑期の差がないことを指摘して農業の兼業化 が大きな原因であろうと発言。有馬は今年度は新患と 再来を含めた調査を行うので差ができるかもしれない と回答。柳沢(自治医大)は諸富の研究に発言し従来の 医学が体育を軽視してきた傾向があるが，農村医学会 は農民の健康增進の観点からぜひこの面を推進してほ しいと希望した。 


\section{母子保健 I}

42. 兼業農家婦人の健康調査成績

$$
\text { 新潟県 中央綜合病院 亀 山宏 平・他12名 }
$$

43. 愛媛県南予農山村における働く婦人の健康調査

愛媛県立北宇和病院農村医学センター 永 見 宏 行・他 4 名

44. 新潟県農村における健康調査成績

新潟県 中央綜合病院 杉 山一教・他12名

*45. 福島県浜通り方部農村婦人の子宮癌検診とその意識の推移について

・福島医大 三嶋 次 郎・他 2 名

46. 過去約 8 年間における子宮癌集団検診結果報告

静岡県 遠州総合病院 高部 かく子・他 3 名

47. 秋田県由利郡の最近の子宮ガン検診成績とガン検診の $2-3$ の問題点について

秋田県 由利組合総合病院 大友 泰 郎・他 1 名

座長 群馬大学医学部教授

过達彦

長野県 佐久総合病院小諸分院長 飯 島 貞 司

42では農家婦人のパートタイマー的工場勤務が近年 全国的にひろがり，その功罪二面についていろいろな 報告がでている。生活を豊かにするための工場労働に より, 家計がうるおうのは当然であるが, 健康をギセ イにしたのでは元も子もないわけである。この報告は 63 名(内 40 才代 40 名)を対象とする健康調査成績であ って, 年令階層別に観察するには少数にすぎる感じが ある。結論では 20 才代のものに健康障害が高率である と述べているが, 僅か 8 例についての所見からは速断 できないので,さらに例数の追加を希望しておく。ま た例数のすくないときに\%を用いることは慎重である べきであろう。そのほか妊娠の有無は別に考虑の必要 があると思う。

43 の報告は上記と類似の問題について, 社会医学的 分析を加え，建設的提案を加えているのでさすがであ る。地域医療における厚生行政と労働行政のより密接 な提携がなければ，改善にむすびつく可能性がそしい ことはいうまでもない，また働く婦人の健康被害を， とくに母子保健の見地から評価する方式を確立するこ とも必要であると思う。

44 の報告は女子を主体とする農民健康調査成績から 年次推移を論じたもので, いわば記述的疫学のデー夕 というべきものである。受診者が同一でない限り，サ ンプリングの問題が入るので, 率の変動を早急に判断
できない。従って，例えば高血圧が昨年より著しく増 加したとしても，環境条件なり，労働事情が悪化した ためか批判できない気がした。そのへんの分析を加え ておけば，よい資料となるものと思う，要するに，臨 床医学的データのみでは, 解釈できない農村医学的背 景があるのが現実である。

以上 3 題を通じて感じたことは, 健康調査と健康管 理の関連についてである。単なる事後指導だけでなく とくに健康教育を通じて行動化する方策をより強力に 導入すべき機運にあるように思われた。

46 では, 遠州総合病院より昭和 41 年から 8 年間にわ たる子宮癌集団検診の成績が総括して報告され，47で は由利総合病院の大友, 森が昭和 47,48 年に実施され た子宮癌検診の結果を発表された。

おのおの年間約 2,000 人におよぶ検診を行い，上皮 内癌, 浸濶癌ないし体部癌を発見されるという成果を あげられている。そして演者はともに50６0才以上の いわゆるハイリスク・グループの高年令者の受診率が いぜんとして低率であることを警告され，その受診率 の向上が急務であると強調された。

子宮癌集検はとかく容易に実施しうる検診であると考 えられがちだが, 関係者のご努力は follow upの問題を含 め, なみたいていのものではないことを追加したい。演者方 の業績に敬意を表するとともに今後のご活躍を期待する。 
$600(50)$

\section{母子保 健 II}

48. 農村婦人の流産 長野県 佐久総合病院小諸分院 飯

島 貞

司

49. 佐久総合病院における帝王切開例の検討

長野県 佐久総合病院 斉 藤 長 士・他 2 名

50. 当院における晚期妊娠中毒症に関する二，三の検討，主として新生児について 長野県 北信総合病院 渡 辺 卓 二・他 1 名

51. 農村乳児の貧血について（第 3 報）——自然治㦄例の経過について 北海道栄養短大 田坂 重元

52. 農村における乳児の血清葉酸值と母親の血清葉酸値及び母乳との相関関係について 秋田県 平鹿総合病院 千 葉 二 美 夫

53. 一地方都市（市部と農村部）における育児環境の現況について

秋田県 由利組合総合病院 小田原久子・他 3 名

座長 北海道栄養短期大学教授田坂 重元 静岡県 静岡厚生病院副院長 久保田 裕之

母子保健 II うち 48〜 53 を受持ったが 52 は誌上発 表になった。

まず, 48 の農村婦人の流産について，長野(自県), 秋田, 広島の 3 県に出張観察された結果, 自県が 3 回以上の 流産が多く，春の農繁期に多い点，また，耕うん機の 振動が主誘因であったが，それについてなんら予防的工夫 がなされていないので今後これらについての研究と指 導をしたいと結んでおられた。

48に対し, 田坂(北海道・栄養短大) から, 耕うん機 のり物流産の予防に早期よりの岩田帯は効果がないか と質問があった。これに対して飯島は，いわた帯一さ らし木綿の使用は農村でも减った。耕うん機の振動は 激しく, いわた帯をおなかに巻く程度では流産を予防 できないと述べた。

49 では, 帝切例の検討をしたが, 統計の結果逐年增 加しているが，なかでも反復帝切が多いことが判明し たので，母子保健の上から初回帝切を慎重に行うべき とのことであった。

これについて田坂より帝切が将来幼児又は母親の情 緒に障碍がないか，私が北海道での観察では 3 才児に ついて帝切分婏児に情緒障碍児が多かったし，母親の 矢田部-ギルフォード性格テストで情緒不安定のものが あったが, という質問があったが, 斉藤は, 中島(日赤 産院)の発表(臨床婦人科産科 28 巻 8 号)で「全分婏例
について帝切児において統計学的に有意の差をもつて 精神発達障碍の発生頻度が高い。しかし成熟児例のみ について検討してみると有意の差は認められない」と のべていると答えた。

50 は，晚期妊娠中毒症があることによって，未熟児 出生, 低血糖症, 低 $\mathrm{Ca}$ 血症, 仮死など 6 乃至 $20 \%$ あ るに鑑み, 妊娠初期よりの管理, 即ち母親学級, 食生 活, 住宅改善の指導により 2 分の 1 に減らすことが可 能であるとのべた。

これに対し, 田坂は, 奇形と妊娠中毒症との関係に ついて質問した。

これに対して渡辺は, 妊婦中毒症によって奇形が出 来るのではなく, 奇形児を生むような母体は妊婦中毒 症になり易いのではないかと考えていると答えた。

また久保田(静岡厚生病院)から, 妊娠中毒症未熟児 の合併症中, 低血糖症及び低 $\mathrm{Ca}$ 血症の診断的根拠に ついて質問があり, 渡辺は, $\mathrm{Ca} 4.0 \mathrm{mEq} / \mathrm{L}$ 以下で低 $\mathrm{Ca}$ 症状があり, カルシウム剤の投与で症状が改善された ものを低 $\mathrm{Ca}$ 血症とし, 低血糖症の診断はデキストロス ティクスで $25 \mathrm{mg} / \mathrm{dl}$ 以下殆ど呈色せず, 高張糖液静注 で症状改善されたもので, 殆どの例について実際の定 量で確認してあると答えた。

また田坂は，晚期妊娠中毒症の晚期に特に強く現わ れる中毒症状にどんなものがあるかと質問したが, 保 
倉 (長野·北信棇合病院) は, 広義の妊娠中毒症は, 妊 娠初期の悪阻等も含まれるもので, ここでは, 妊娠後 期に「浮腫, 高血圧, 蛋白尿」のいずれかを症状とし て発症する，狭義の妊娠中毒症に限定したと答えた。

また, 岡村敏弘(秋田・由利組合)より発言あり, 晚 期妊娠中毒症は(衛生統計にいうならば)一般的に妊娠 8 力月以降をいうがいかがか, 先天異常の発生は妊娠 初期にみられることが多いが妊娠中毒症と先天異常 (奇 型)は，はっきりした因果関係は言明するのが難かしい と述べた。

51 で田坂は, 乳児の資血において軽度の者について, 勉めて日光紫外線照射により回復したもの $50 \%$, 離乳 食を早期に実施して $40 \%$ の回復をみ, 日光浴, 早期離 乳, 全身運動, 昼寝等総合改善で約 $70 \%$ の効果をあげ ている点から，仮性筫血に対する自然治瘾を指摘した。

岡村は，筫血の改善に日光浴をとりあげた理由，ま た離乳食の質は全例同じものを与えたのか, 調理方法, 食品等はどうかと質問し，田坂は，第 1 報で当学会で 発表したように乳児は大部分仮性筫血像を呈している ものが多いのでクル病予防, 体力增強をかね日光の紫 外線を照射させることがねらいである。離乳食の質的 面では植物性蛋白(ミソ汁, トーフ等)とミネラル(海草, 緑色野菜等をスープ，マッシュ等にして)をあたえるこ とを指導し, 細かい献立上の配虑は特に行なっていな いとのべた。

斉藤(長野・佐久総合)より母乳, 人工栄養の間に筫 血の差があるかと質問があり, 田坂は, 純農家の 4 乃
至 10 カ月の離乳期間中の乳児では母乳児は離乳がやや おくれる傾向があるので，鉄欠筫血が人工栄養児より 多いようであるが，有意差を認められなかったと答え た。

53 の共同研究である秋田県の都市と農村の育児環境 についての昭和 44 年と 48 年の比較では, 出生時の身 長体重共 48 年の市部が上回っており, 出産場所でも施 設の整備で農村地区に病院分婏が多くなってきている。

なお，母乳栄養は自宅助産施設に多かった。育児の 主体はまだ祖母にゆだねており, もっと雇用側に一段 の協力がのぞましい等, 生活の近代化に伴い農村の育 児環境についてもっと改善すべき点の多きを指摘され ていた。これに対し, 飯島(長野・佐久総合, 小諸分院), は，1）母乳栄養率が何故農村でも低下したのか, 農 村婦人は妊娠中毒症児や帝切児を分婏しないように注 意してほしい。2 ) 母乳分泌には母娘相関があるよう だ。3）母乳栄養の優秀性を農村婦人に教示すべきだ と述べた。

また岡村は, 母乳栄養の少ない理由として, 産科で 安易に人工栄養を与えること, 施設分娩では第 1 子が 多いこと, 共稼ぎで早く母乳を切り上げるからでない か, 以上三つでその他にマスコミの宣伝に農民が弱い ことも理由の一つになっているのではないかと述べた。

要するに全体を通覧してみると, 農村の母性並びに乳 児の保健，予防面が都市に比し立ちおくれが目立って いる点から, 改善指導に一層の迫力が望ましいもので ある。

\section{譏械化と健康}

59. 農業機械化による疾病障害の臨床的研究——昭和48年度全国調査結果— 日本農村医学会・農業機械災害研究班 佐々木真爾 ·他 1 名

60. 野辺山高原野菜・酪農農家における近年の大型機械装備と年間投下労働量に関す る実態調査……………………日本農村医学研究所 萩 原篤・他 4 名

61. 農業災害特にトラクターに因る死亡事故調査

北海道 帯広厚生病院 伊藤紀克

座長 福島県 白河厚生総合病院長 峯 山 泰

佐々木らは, 昭和 46 年以来厚生省委託研究として日本 農村医学会がおこなっている農業機械による健康障害
に関する調査研究の一部として昭和 48 年も全国 57 医 療機関より臨床例 434 例を集計し実態を分析した。高 
$602(52)$

性能大型機械の普及傾向の故か症例は增加して且つ重 症化の傾向にある。年令別では 40 才以上が過半数を占 めている事はいろいろな問題を示唆する。機種は合せ て 23 種にも及び第 1 位は相変らず歩行用トラクターに よるものであるが 46 年時に比してコンバイン乗用トラ クター等の大型機械によるものの增加が特徵的である。 発生原因を探求するため各機種毎に作業と災害をおこ した部位を詳しく検討しているが，これは個々の機械 のもつ危険箇所を明確にして改良並びに操作上の注意 を喚起するのに役立つ。治療経過では過半数が 2 週以 上に及ぶことは機械の大型化傾向の故であろうが由々 しいことである。機械の安全対策, 運転者の教育等の 総合的な対策を必要とするとしている。

萩原らは長野県南佐久郡南牧村野辺山地区の農家 20 戸について大型機械化と投下労働量の関連について実 態調査を行なった。調査地区は高原野菜と酪農の大規 模専業農家であるが, 農業機械の利用時間は総投下労 働時間の $10 \%$ にすぎない。播種, 除草, 間引, 収㮃の 大部分の作業は人力労働で機械化は労働時間の軽減に 役立たず却って作付面積の拡大をきたして人力労働の 增大をもたらす面もあるとしている。

伊藤は北海道十勝地区の農業機械が大型化し台数が 急增しているとし，特にトラクターについて外国製機 械が多く安全装置を取りはずしたものが多い上婦人等 の運転未熟者増加の結果死亡増加を注目している。

特に農林省が制定した規則, 法令, 通達がゆるくて 拘束力が弱く行政の目のとどかぬ所で守られていない とし，トラクターの死亡事故を減少するには教育と行 政の監督が必要だとしている。
以上に対して演題 60 に中村 (長䗁大) より機械化労働 時間が総時間に占める割合が低率に留まっているが, 営農形態別には現状は如何なる程度であろうか, 又将 来の進展の目途は如何かとの質問があった。これに対 し萩原は稲作については機械利用率はもう少し高いと 思うとの返答があり，森岡(日大衛生)からは(1) 報告し た機械作業比率の数字は蔬菜労働のみのもので, 酪農 関係の飼料作物については調査対象の大規模酪農農家 で $50 \%$ 以上にも達した。(2)蔬菜作中心農家でも最近は 30〜 60 HPのトラクターが導入されて僅かの耕耘作業に 高能率が計られているのは, それだけ機械化の不可能 な人力作業の比重との対比で考えてみる必要がある。 との追加発表があった。

演題 61 に対して酒井(新大農)より北海道のようにト ラクターの普及密度が高く, 又多種の作業に用いられ ている場合には, 事故調査は「トラクター十作業機」系 別に分けて考えるべきではないかとの意見が出され， (1)トラクターは免許なしでは公道を走行することはで きない(講演要旨では誰でも運転できるという表現であ るが)。(2)安全フレームについて現在装着を法的に義務 づけているのはヨーロッパ 9 力国である。なおわが国 に輸入されているトラクターのうちチェコスロバキア 製のZetor はフレームを標準装備としているとの追加 があった。これに対し伊藤から道路上での免許を必要 とする。実際は, 行政の目が殆どとどかない場所のた め守られない。私はやはり一般自動車なみに法的規制 を作らなければ自主的だけでは事故滅少を望めないこ とを強調したいと答えた。 


\section{労 伯生 I}

62. 本邦諸地域農民の血液成分, 体重, 投下労動量からみた年間の生体負担の変動 長大医・衛生 中 村 正・他 6 名

63. リンゴ栽培農民における生体負担の季節変動

·弘前大医・公衛 佐 藤 郁 雄 $\cdot$ 他 2 名

64. 山村農民男女の血液性状の年間変化と農業労働生活の生理的負担

65. 兵庫県下某近郊地域農民の生活と体力について 日大·医・衛生 森岡 三生・他 3 名 ・神戸大・医・衛生 戸 田嘉秋

66. 四国地方における蔬菜農民の生体負担 徳島大・医・栄養 白 井 伊 三 郎

67. 筑後地区農民の生活と労働負担, 特にい草農家の労働負担について 久留米大・医・環衛 高 松誠・他 4 名

68. 長崎地方における水田, 蔬菜, 果樹 (みかん) の各労動負担の比較 長崎大・医 - 公衛 光 武 典 之・他 3 名

$\begin{array}{lllll}\text { 座長 長崎大学医学部教授 } & \text { 中 } & \text { 村 } & \text { 正 } \\ \text { 日本大学医学部助教授 } & \text { 森 } & \text { 岡 三 } & \text { 生 }\end{array}$

ここにまとめられた 7 演題は，冒頭中村が紹介した ごとく, 昭和 47,48 年度にわたる文部省科学研究費に よる班研究の成果である。農業経営の近代化にともな う農民の労働負担の現状というテーマのもとで, それ ぞれの特徴ある地域農業を対象とした点でユニークな 課題群ということができよう。

62 は, 全体のとりまとめを共通の調査分析手法である 年間月毎の生活時間調査による労偅時間, 消費熱量, 体重, 血液 $\mathrm{Hb}$ 浱度の変動成績についてのべた。すなわ ち, 農業労働従事時間は水田農民で最も短かく, 果樹, 蔬菜農民の順であるが, 経営種目による地域差がなお 大きいこと, 消費熱量は何れも $3,000 \mathrm{cal}$ 以下になって おり, 過去 15 20 年前に比べ, 特に水稲作での投下労 働量の減少が顕著である。しかし月別推移は 4 月〜 8 月の農繁期における労働時間, 消費熱量の增大が, 体 重や血液性状の低下と平行し, それらは又, 地域差と も相応している点で, 年間の労働負担指標として有用 であることを指摘した。

63 はリンゴ栽培農民の 10 年前の調査と比較し, 6 月, 9 月の農繁期では労動時間, 消費熱量, 体重減少等軽 減されている反面, 農閑期の農外就労の增加が顕著で
あることを指摘し，栄養摂取面でも改善の方向が示唆 された。

64 は, 長野地区山村部の水田と酪農, 或は花卉栽培 農家を対象とした成績から, 労働負担が農家毎に経営 作目との関連で多様化していること, 労働実態をふま えたきめ細かい健康管理が重要性をましているとした。

65は, 播州平野の近効農民, 水田あるいは八ウス栽培 を生とする両地区を対象に共通調査に加え，栄養摂取 量, 体力テスト, 血圧, 検尿, 自覚症状等の健康相談 の成績から, 農業の多様化の中で, 体力面でも個人差 が大きく，一部に体力低下がみられる点を指摘した。

66 は, 四国地方の水田, 酪農, そ菜を複合化した近 代経営は，年間労働時間の配分で一面の合理性をもち， 機械化により男子農民では労作量値の低下をもたらし ている反面, 各期間のハウス農業が特に主婦の農作業 従事時間の增大から, 夏冬 2 回の農繁期に対応して, 体重, 血圧, 皮脂厚, 血液性状等の機能指標の変動に 過重な負担が推測されることを強調した。

67 は, 筑後地区農家としして特異的な経営であるい 草栽培農家では一般農家に比し，6月，7月を中に 労働負担がきわだって大きいことを, 消費熱量や血液 
$\mathrm{Hb}$ 值の年間変動の中で明らかにした。

68は, 長崎地区の水田, そ菜(すいか), 果樹(みかん) と経営別農家群の比較から, 農業労働時間や農繁季節 の差が, 体重, 血液 $\mathrm{Hb}$ 值の年間变動と相応して認めら れること，とくにそ菜農民には個々作業の RMR より， 従事時間の過長性が負担要因として大きいことを指摘 した。

質疑では, 酒井(新潟大)より RMR 測定や作業分析の 精粗による消費エネルギー算定の精度如何と作業負担 の表示に心拍数の利用が示唆された。中村, 白井は生 活時間配分の正確な計測評価が熱量算定に重要なこと,
また作業分析も RMR の測定条件を十分考虑して行う べきを強調した。心拍数は個人差や環境要因にも左右 されるが, RMR の代替指標としてょり，それ自体総合 的な評価尺度として意義づけられるとした。

総じて農業労働を対象とした労働生理学的分析も, 技術変化にともなう農作業形態の変容の中で進歩させ る必要が痛感されるとともに, 特に蔬菜農業や農村主 婦の労働では, 重筋労働の観点より，作業姿勢や集約 的な手作業密度が過長労働時間と結びついている所に, 労働負担の主要因がある点は, 今後の解明課題である と思われた。

\section{労 働生 理 II}

140. 高原野菜, 酪農農家の春季播種ならびに秋季収穫時における農作業時間と疲労に

関する事例調査. 日本農村医学研究所 佐々木真爾 ·他 3 名

* 141. 共同防除従事者の生体負担について 弘前大・公衛 $⿴$ 谷三郎・他 2 名

142. 農業従事者の体力に関する調査研究——農・非農従事者の体位, 身体機能の比較— ·秋田県 平鹿総合病院農医研 黒 川誠 悦 $\cdot$ 他 7 名

座長 久留米大学医学部教授 高松誠

労動生理に関する 3 題を報告していただいた。農村 医学の基本は, やはり地道な労働生理の研究の積みか さねに依存することが多いので，このような報告が増 えるのはよろこばしい。一般講演の最後の時間であっ たから, 時間も余裕があり, 発表者も意見を充分に述 ベられたものと思う。

140 は, 高原野菜づくり農家の 6 月の種まき及び定植 作業と, 10 月の収穫期作業の RMR, タイムスタディ 及び生体負担度を測定した事例調査を報告した。討論 は疲労検査としてのフリッカー值の測定に意見が集中 した。森岡(日大医) は, フリッカー值の変化が疲労と は考えられないが, 変動経過が作業実態とどう関係し ているか考えたいと述べた。産業労働とは違って日毎 に変動の多い農作業の負担度の究明にフリッカー值を 使うことに，私はあまり興味を示さないが，臼谷(弘大 医)や藤原 (兵庫農)は, いい方法であるという主旨の発 言があった。また, 中村(長大医)からフリッカー值の
レベルに 6 月と 9 月に差があったかどうかの質問があ ったが，有意差はなかったようだ。

141 は, リンゴ栽培におけるスピードスプレー(S.S.) を使用する共同防除従事者の生体負担を測定した成績 を報告した。S.S.の騷音が 100 ホン前後であるのはひ どいものだ。生体負担としての生理機能としては, 腎 外水分䔻失量にのみ運転手と防除係とに有意差が認め られたという。森岡(日大医)からオペレーターの散布 作業の RMR 2.0 は単なる運転動作としては少し高すぎ るように思うということと, フリッカー值は前後の 2 回しか測定してないが，作業途中も測れば恐らく高い レベルも得られるから, 変動経過として意味づけられ ると思うという発言に対して, 演者は運転をしながら 小枝を払うという作業も入っているから(高くなるのだ) ということ, フリッカーの測定では仕事のノルマが与 えられている現状では, 経時的に測定することは農民 の協力がえられにくいと答えた。 
142 は, 生活環境の変化にともなって, 農民の体位が どのように変化をしているかをみるために, 秋田県の 横手盆地の平鹿町の農業従事者と非農業従事者につい て, 体格, 体力を測定し，それを 20 年前(昭 29)に同じ 地域の阿気村について, 石井(労動科研・故人)がおこ なった資料と比較検討した成績を報告した。体格では 昔とほぼ同様か，もしくは增大しているが，体力では， むしろ低下の傾向が現われているという。この報告に
対して臼谷(弘大医)から 20 年前に測定された同一人に ついて再度測定していただき，加令に伴って想定され る変化に対して，どれ位の偏差があるかというような 点についても検討いただきたいという発言に対し，菅 谷(平鹿農研)は再検討してみたいと答えられた。故人 の資料が活用されて生きかえることは，限りなくよろ こばしいことである。

\section{運动器疾患}

69. 木島平村における腰まがりと腰痛について

長野県 北信総合病院 高 橋 貞 雄・他 2 名

70. 農山村における腰痛と農林業従事者の腰椎の加令的変化についての考察

東京医歯大・難治研疫学 大 庭浩・他 1 名

71. 農村地帯における偽性沶椎芒り症について

長野県 市立大町総合病院 狩 谷

勝

72. 農村における膝関節疾患の実態と治療（変形性膝関節症を中心に） 高知県 中村市民病院 柳 沢 文

73. 田植後に発症した手指の総指伸筋腱障害について

·新潟県 三条総合病院 能 登 省 三・他 2 名

74. 大腿骨頚部骨折の治療成績

静岡県 静岡厚生総合病院 三宅 信 明 - 他 2 名

$\begin{array}{rllllll}\text { 座長 } & \text { 北海道 } & \text { 帯広厚生総合病院長 } & \text { 伊 } & \text { 藤 } & \text { 紀 } & \text { 克 } \\ & \text { 静岡県 } & \text { 遠州総合病院副院長 } & \text { 鈴 } & \text { 木 } & \text { 重 } & \text { 世 }\end{array}$

運動器疾患 6 題を, 前半 3 題後半 3 題に分け, 前半 は腰痛に関するもの, 後半は四肢に関するものとして 進行することにした。まず前半の腰痛に関するものは, 多様な農業労働が長期に资椎およびその周辺部組織に およぼす影響に関しての独自の調査方法や，その加令 的な変化についての報告，および加令的な退行変性を 主因とする偽性资椎迄り症が, 農業従事者における高 率な発生と, それに関する治療法の大要が報告された。 農村における腰痛症の問題は以前から本学会の主要な テーマであるが, 今回もまた種々の角度よりこれに関 する研究が発表されたわけである。腰痛がきわめて複 雑な要素をもっているため，農業従事者にとくに多く
みられる農夫症としての腰痛ももまたきわめて厄介な 問題であり，いまだにきめて手がないといわざるを得 ない。

後半 3 題に関しては, まず変形性膝関節症であるが, 農村に多くみられ，とくに女性は男性の 6 倍を占め, 30 才台より発病し, 女性ホルモンの相関性が考えられ る。とくにその治療法にトラジロール関節内注入とい う報告がなされた。これに関して, 疼痛消失の効果は 確実に得られる場合が多いが, 副作用がみられ, 時と して重篤な場合があるため first choice として選ぶこと にかなり疑問があるとの追加論議がなされた。これに 対して, 演者は予防処置として注入前べナ皮下注, シ 
$606(56)$

一ネ固定および注射後 20 分間の安静観察の要ありと述 べている。変形性膝関節症の治療としては, 種々の方 法が行われてきたが, トラジロール注入の経験を持た れた方々はきわめて少ないと考えられるだけに，効果 著明の反面, そうした起り得る副作用には充分の観察 が必要と思われ，なお多くの症例とその経過観察が必 要と思われる。田植え後の総指伸筋腱障害については, 文献的には, 保存療法で治療可能とされているが, 重 症例について, 積極的な手術療法を行い好結果を得た との報告がされたが,一般的には稀であり農村地帯に 主としてみられるこうした疾患に関して貴重な報告で
あり，術後の長期の追跡調査を是非知りたいものであ る。ついで大腿骨頸部骨折の治療について, 平均寿命 が延びてきて, 老人の頸部骨折が增えてきており，そ の手術方法の変遷と早期リハビリテーションが強調さ れた。本疾患は難治性で, とくに老人において, 厄介 なことは衆知の事実であるが, 平均寿命の増大ととも に今後ますます老人の大腿骨頸部骨折はその数を增す と思われるその場合骨折の治療はもちろん，合併症の 予防が大切で, そのためには，なお一段の早期離床, Rehabilitationの充実が必要となってくると思われる。

\section{出稼ぎ問題}

75. 出稼ぎの疫学的研究（第 1 報）

東京医歯大・難治研疫学 柳 沢 文 徳

76. 東北農村の出稼ぎに関する研究, 第 9 報 就労前 - 中の健診と問題点 秋田県 平鹿総合病院・農医研 小棚木章・他 6 名

座長 秋田県 由利組合総合病院長 和 泉 昇 次 郎

75 は, まず, 「出稼ぎの疫学」か「出稼ぎ者の疫学」 か, また, 「疫学」という用語の導入について, 問題提 起をされた。それには，まず出稼ぎ者の数を拥むこと が重要で, 農林省に二つの統計資料があるが, 両者に にはかなりのくい違いが見られ，その実態把握には困 難がある。それ故地理的地方自治体的に, 特に市町村 単位に重点をおいて調査されることが必要である。し かし，国家統計にはそれなりの意味があるので，これ を基にして, 都道府県別の検討を行った。その結果は， 減反問題などとも関連して出稼ぎが増加している県も あり，横ばいのところ，また逆に減少しているところ も見られた。従って，ここに地理的位置づけを明らか にする必要があり，また農家の兼業内容の種類別を明 らかにして, 今後はこの面からの検討が必要であると 述べられた。次いで, 出稼ぎ者の健康破壊の面を, 青 森県市町村のアンケート調查から, 出稼ぎ中の死亡が 1,000 人対 1 人, 疾病事故による帰郷が 1,000 人対 3 人 という成績であった。これらの数字は秋田県において もほぼ同様であるが, 最低の数字であると理解すべき
であることを附言された。

76 は, 秋田県平鹿地方の農山村を中心にした出稼ぎ 者を中心に, 過去 4 年間実施した検診成績から，「農夫 症」が漸次增加した $(22 \%$ から $40 \%)$ ことから出稼ぎ 者には疲労の固定化が推定されるとし，また高血圧者 $(12 \%$ から $22 \%)$, 有疾病率, 有病者率增加, また要 注意, 要医療も $(21 \%$ から $39 \%)$ 増加していることを述 べ, 更に, 出稼ぎ先(東京)における一日検診の成績で も, 出稼ぎ者の検診成績に比べて, 高血圧, 虚血性心 疾患をはじめ検診各項目に悪影響が認められたとして， 出稼ぎが出稼ぎ者の健康破壊の因子となっていると述 ベた。なお, 出稼ぎ中に, 労災事故, 交通事故また脑 卒中の発症など多く, 後にいろいろと問題となるとこ ろから, 職場選択に併せて, 行政また医療機関として, これらにどう対処すべきか, 今後の検討が必要である と問題提起をされた。

追加討論では, 柳沢(文)から, 出稼ぎ者の健康破壊 また，特有な疾患ということが問題なのだから，疫学 という立場で正面からとりあげる必要があり，また， 
そういう研究姿勢をとる方がよい。酒井(新大農) は, 留守家族の問題もあるので「出稼ぎの疫学的研究」で よいと思う，と発言があった。藤井(札幌・勤医協)は, 北海道農民の出稼ぎについて追加し，とくに利尻，礼 文といった離島では, 労働条件の悪いところが多く, 毎年 10 数名も死亡している。伊藤(帯広・厚生)は, 北 海道南部でも出稼ぎ者は耕作反別の少ない農家に多い。 しかし，若い人には都会に憧れる観光的な要素も無視 できないと思う，との発言があった。それに対して， 小棚木 (秋田・平鹿), 秋田の出稼ぎ者の大部分が一家 の大黒柱であり，生活資金をうるため $78 \%$, 経営資金 をうるため $10 \%$ であるが, 若い人では観光をかねるも のも混在している。出稼ぎ者の全員が覑しいためでは ない。また, 菅谷(秋田・平鹿)は, 秋田県出稼ぎ研究 班による2,000 名に対するアンケート調査によれば, 「観光その他」が 47 年 $7.8 \%, 48$ 年 $1.4 \%$ で, 農家の 現実はきびしくなっている。柳沢(文)は，観光につい ては老人にもある。出稼ぎ者のうち 20 30才代が約 20 \%を占め, 中には観光というものも確かに混在してい る。しかし, 疫学の中心となるのは, 50 才代が多いと いう事実である。北海道は土地が広いために, 出稼ぎ 人口が目立たない。昔は“蟹工船:のごとく漁業への 出稼ぎが多かったのが，近年は形が変ったのではないか。 一般農村の経済地帯別では, 都市近郊及び平地農村で は出稼ぎ者が1 数 \%, 農山村では $15 \%$ である。従っ て, きめ細かくみる必要がある。兵庫, 富山も出稼ぎは 多いが, それぞれ酒造業, 行商といったもので問題に ならない。従って, 県レベルのもの, 市町村別のもの, それぞれその実態に即応して，国の施策もたてる必要 があるのではないか。また，四国・九州では，10２0\% が県内でまかなわれている。阪神等にでるにしても距 離的にも，また業種的にいっても東北よりは条件がよ
い。東北では, 東京地方を中心として建設業に集中し ている。やはり東北が大切, 秋田県では特殊技能者の 養成などきめ細かくやっているのは参考になる。と全 国的にみた出稼ぎの動向について述べられた。

さらに, 出稼ぎ健康破壊の原因となる理由, その対 策について, 座長より意見が求められた。

小棚木 (秋田県・平鹿)は, 対策として, 出稼ぎ者の 検診が大切で， あとはアフターケアーの問題だが，現 状では個人的に各自が自分の健康管理をするよりほか はない。これをとびこえる健康管理対策が必要である。 出稼ぎ前の検診の結果では, 要入院は問題ないが, 要 治療は徽底できない。菅谷(秋田・平鹿)は, 検診を受 けに来る人は問題は少ないが，来ない人の方に問題が ある。平和島で東京方面の出稼ぎ者に対する一日検診 を行ったことがある。参集者は 160 人だったが，出稼 ぎ前に検診をうけたものは $20 \%$ にすぎなかった。我々 の手の届かないまた, 病院で処理しきれないのが多い。 また, 出稼ぎ不可とされた者は 2 回目からこないとい う問題もある。いずれにせよ, 職業選択の問題も含め て, 健康上の注意をするのだが，そのアフターケアー が徽底していないのが実情である，と重要な意見が追 加された。

出稼ぎは，今日の資本主義的社会体制においては， 不可避的な現象であり現実である, 出稼ぎが健康破壊 の要因となっていることは重要で，その対策は，一医 師また，一医療機関の力のみを以てしては，自らそこ に限界があり，行政また組織などとも密接な連墼を保 ちながら，それぞれの地域に応じた対策をいかに樹立 しここをいかに実践するかということにあるように 思われる。それにしても，そこには充分なる国家的施 策が強く望まれるところである。 
$608(58)$

\section{健 康管理 I}

77. 茨城県における農民の健康を守る運動について

茨城県 水戸協同病院 鈴 木 達 也·他18名

78. 長野県下における集団健康スクリーニングの試み——その 1 , その組織, 運営,

実施状況について—…………長野県農協中央会 古 厩元・他 3 名

79. 長野県下における集団健康スクリーニングの試み—その 2 , 昭和 48 年度の成績

について………長野県厚生連・健康管理センター 松 島 松 翠・他12名

80. 福島県下の 4 ケ年間の健康調査結果成績について

福島県厚生連・農医研 菊田重治

81. 埼玉県における農村保健調査研究事業

埼玉県 幸手病院 水 間 正 冬.他 7 名

82. 当院における保健婦活動

三重県 中央総合病院 落 合 正 子・他 4 名

座長 東京医科歯科大学教授 柳 沢 文 徳

福島県 塙厚生病院長 岩間倫男

“農民の健康を守る運動”は，各県独自の方式で進め られているが，従来の巡回健康診断中心の小規模なも のから, 検診内容向上, 守備範囲拡大を目標に, 近代 の進んだ諸種の機器を導入した大規模な検診方式へ, 漸次移行する傾向が見られる。そして健診活動は, 医 師対個人の関係から，その間に多くの機械が介在する 医師及び医療従事者対集団の関係に変りつつある。

この群の発表では, 各演者より, それに伴って当然 でてくる運営上，資金上の問題から，関係機関，団体 (県, 町村, 農業改良普及事務所, 保健所, 医師会, 農 協内各組織等) よりの援助, それらとの連携, 協調がな されている事実, およびより一層の必要性が強調され た。また，活動をより効果あらしめるには，事前・事 後指導の充実が最も大切であると, 共通的な報告がな された。

77 は, 茨城県における 47,48 年度の検診成績につ いて発表, 結論として, 市町村, 関係機関との連携強 化と, 検診のみでなく, “適切な事後指導” が重要であ ると述べた。柳沢(座長)および西成(秋田)より，それ ぞれ血色素, 血清タンパク量の判定基準に対する質問 があったが，これらに限らずデータの数值の判定基準 に，統一されたものが学会にない現況である。で，柳 沢(座長)より,この問題に関して, 口演終了後討議す
る提案が出されたが, 時間不足のため討議されなかっ た。今後の課題として, 統一してほしい。78，79は, 長野県における「組合員の健康を守る運動」を全県運 動として拡げ，推進する方策として，厚生連に健康管 理センターを設立し, オートアナライザー, コンピュー ターの導入を計り, 健康管理の高度化, 能率化を計っ た“集団健康スクリーニング”について，その組織， 運営, 実施状況および 48 年度の実施成績をそれぞれ 発表した。この発表は, 他群の 40, 93 と一連のもの であるが，よくぞここまで手を付けたの感が深い発表 であった。小倉 (千葉大・農医研)より，1）問診のみ で異常と判定されることもあるか。2）採血の時間, とくに血糖値測定は空腹時に行うのか。3）他の成人 病検診(胃癌, 子宮癌検診等)をどのように組み入れて いるか。又, 将来の方向は, の質問があった。松島は, 1) 総合診断は, 自賞症状, 検診值, 医師の触診結果 を総合して決定している。従って，諸検值に異常がな くても，自覚症状のみでチェックされる者が当然でて くる。2）採血は，とくに空腹時と限っていない。問 診で, 空腹時, 食後 60 分, 食後 120 分の 3 段階に区分 し，別に作製した判定基準と照合する方法をとってい る。3）現在, 胃癌, 子宮癌検診は, 一応従来の検診 車を利用している。しかし，将来はそれらを含めたド 
ック式の総合的なものに高めていきたい，と。次いで 鈴木(水戸協同)より，この方式では膨大なサンプルが 集まる事より，検診成績には見本とするに足るものが 多く出るものと考える。当方でも地方へ出て採血し, オートアナライザーで分析した事があるが, 採血方法, 検查までの時間, その運搬方法, 気象条件等々の問題 で，その成績判定に混乱を来たした経験をもっている。 そこで，この際我々に，これらの具体的な条件を設定 しての検査成績を発表して頂ければ大変幸せである。 と発言があった。80は, 福島県下の 4 ケ年の健康 調查成績のまとめ, 81 は, 埼玉県下の過疎, 専業, 兼 業の 3 地帯から更に各 3 ケ所のパイロット地区を選ん での検診結果より, 筫血は標高, 年令等の関係も考虑 すべきである。また，事後指導のよく行われた地区の 成績は向上したと述べた。82は, 検診活動においては, 事後指導と同様に事前指導も重要であるとの観点より,
保健婦の立場から, 受診勧奨の目的で種々のユニーク な趣向を考えており, 現在は検診時, 楽しい体力テス 卜を行なっていると報告。これに対し，柳沢利（自治医 大)より, 最近, 農民の筋力低下の報告もあるので, 体 カテストのデータも出してほしいと要請一あった。

次いで, 総括的な質疑として, 77 に対し, 宮田 (岐 阜大・医・衛生)より，“適切な事後指導とは如何なる 事か”の質問があり，田谷は報告会および個人指導を 中心としたと答えた。それに対し宮田は, 田谷の発表 の中で，もしある集団に筫血が $5 \%$ 以上あったとする と, その地域は何か共通健康障害因子のある問題集団 である，とのWHO の指摘を述べられたが，調査の中 でそのような集団があったならば, 積極的に疫学調査 をする等して，その問題集団から共通健康障害因子を 取り除く事も，重要な事後指導と考えると意見を述べ た。

\section{健 康 管 理 II}

83. 木島平村全村健康管理 9 年間の成果と反省

長野県 北信総合病院 泉 山富 雄・他 5 名

84. 遠隔無医地区の健康管理について……北海道 旭川厚生病院 小西 行 夫 ·他 6 名

85. 上野村における住民健康管理一一気象観測と生活改善事業

·群馬県 藤岡保健所 大 月 邦 夫

86. 新生開拓農家の労働と健康 …………茨城県 土浦協同病院 田 谷 利 光. 他 7 名

87. 家族労動適正化事業による健康管理意識の変容

青森県 弘前地区農業改良普及所 佐 藤 郁 夫

88. . 地域医療（僻地）のレベルアップについて（健康管理と主治医制を主張）

高知県 佐賀町国保拳八診療所 疋 田 善 平

89. $\mathrm{R}_{4}$ 型保健所の共同保健計画における健康管理活動についての考察

愛媛県 八幡浜保健所 平井 和 光 - 他 2 名

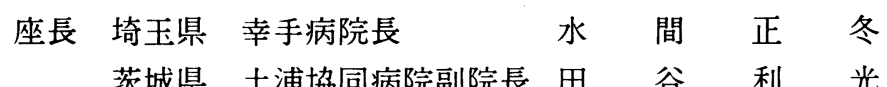

日本農村医学会の重要な仕事は地域の健康管理であ ることはいうまでもない。しかも，健康管理というも のは，おしつけるものでなく，農民の「気持ゆたかに， 安心して働きたい」という願いから始められるもので
ある。

前群が健康調查の成績と新しい集団検診法について の発表であったのに対して，この群では，その成果と 反省あるいは改善策についての報告がなされた。 
$610(60)$

すなわち，83 は昭和 40 年来 9 年間にわたり，長野 県下木島平村の成人層の検診を行なってきた結果，有 病率と潜在疾病の減少, 高血圧率と尿蛋白陽性率の低 下など, いちじるしい健康の改善がみられた。しかし， 検診の内容がマンネリ化して受診意欲が低下してきた。 不受診の理由として豪雪, 老人, 病人のためというほ かに農外就労のため不在であるとか村及.び病院側の啓 蒙不足のため農民の意識が健康面を中心として考える に到っていないなどがある。それに対して, 検診費が 公費で行われるようになればマンネリ化を打破できる とのべた。もちろん, 今後もつづけられてゆくのであ ろうが，八千穂村検診のごとく，健康增進のみならず, 学問的探求についての新しい試みも必要であると思う。

84 は, 昭和 44 年来 5 年間にわたり, 北海道中川町 の無医地区を検診してきたが，年 1 回地域住民と接触 するだけでは適切な指導もできず，マンネリ化から受 診率も低下している。これでは健康管理ができるか否 か疑問であると考え, 地区と病院の保健婦の連絡を密 にして，住民の健康上の問題点を解決のつくまで担当 してもらい, 検診班の出動も月 1 回を目途としている との発表があった。本院から $180 \mathrm{~km}$ もはなれた地区だ けに苦労のほどが偲ばれる。

85 は, 昭和 42 年来 7 年間にわたり, 群馬県下大野 村の成人病検診を行なってきたが, 住民の自主学習と しての気象観測の結果が発端となって開始された内便 所設置奨励について紹介した。このことにより冬期間 における脳卒中予防, 老人衛生に成果があがるものと 期待される。なお，同村では総額 1,000 万円を予算計 上して，外便所を一掃しようとしている。この姿こそ 真の政治というべきであり, 農村医学が社会医学とし て高く評価される所以である。なお，長谷田(富山)か ら室内気温の変動と暖房についての質問があり, 外便 所と併せて居間の冬期暖房の問題提起がなされた。

86 は, 茨城県新治郡出島村の新生開拓農家の労働と 健康について調査した結果を報告した。82 戸を対象と し, 所得の少ない順に $\mathrm{A}$ 類型(兼業農家)， B 類型(副 業農家), $C$ 類型(専業農家)に分け, 昭和 48 年 6 月と 49 年 6 月に行なった成績を比較検討した。第 1 回の調 査では健康状態は悪く, 特に高血圧, 筫血が多かった が，農事改良普及員等の協力を得て，集落農家に残る 生産第一主義を健康第一主義に改め, 農作業集中の緩 和, 食生活の改善等につとめた結果, かなりの好転を みるに至ったという事である。

87 は, 青森県南津軽郡浪岡町五本松という部落の専 業農家 50 戸の経営主と主婦を対象として, 労働, 生 活, 健康等の状況を調査した結果, 主婦の筫血が多く,
また，高血圧，農夫症も多く認められ，疲労状況も悪 く, 体力テストでは敏捷性, 平衡性に欠けていること を報告した。この中でとくに筫血者に対して鉄郕を 20 日間投与したところ, 筫血は著しく改善され，農夫症， 自党症状も改善されたという。

更に，この地域においては筫血者グループ，高血圧 グループなどが結成され，住民の健康管理意識の高め られていることが述べられた。

88 は, 高知県幡多郡佐賀町拳の川診療所の医師とし て, 僻地医療のレベルアップについて, 過去 2 年間に わたり，臨床面からの住民健康管理を主体とした患者 の迴遊受診を利用しつつ主治医制の必要性を説得し， 教育につとめ, 徐々に効果をあげているという報告を した。とくに紹介受診をすすめ，健康台帳を作製した りして, 臨床面からの健康管理の効果について強調さ れた。

89 は, 爱媛県八幡浜保健所管内の過疎化の激しい地 域での総合的な健康管理について報告した。それによ ると疾病予防では有病率は減少傾向を示し, 潜在疾病 率も改善されたという。また, 食生活の面では, とく に地域組織の自主活動による共同献立, 共同購入, 共 同育苗による野菜作り，農繁期の共同炊事等が各地に 誕生して成果をあげており, 更に, 地域組織活動とし て各地に総合保健体制が確立され，健康管理意識の向 上していることを述べられた。

なお，高科(広島・佐伯)から食慨調査について質問 があり,これに対して田谷, 臼谷(弘前大・公衛)から いずれも動物性蛋白質の摄取不足という答えがあり, 更に臼谷は，鉄欠乏の原因としては，痔，胃腸疾患に よると思われる者が数名いたが，大半は原因不明であ つたと追加した。和田(奈良下北山村国保診療所)から は僻地における年 1 回のお祭的検診に対する批判的質 問と，更に，僻地医師不足の悩みが訴えられた。これ に対して正田から，1日検診でも利用方法を考えれば 意義があると述べられたが, 僻地医師の問題は今後に 残された一つの大きな問題であると思う。

高科からは, 紹介状受診について, 医師側にも問題 点があると指摘されたが, 紹介状の書き方については 医師も十分協力すべきであると思う。

以上，いずれも地域住民の健康管理に積極的にとり くんでおり，ただ単に健康診断をしたり，栄養調査を したりするだけでなく，どのようにすればより成果を あげることが出来るかという事について多大の努力が なされていることが十分にうかがわれた。健康管理と いう仕事は，実施面でいろいろむずかしい問題が伴う ものだが，演者達はそれぞれ工夫をこらして，かなり 
の成果をあげているようである。このことは今後, 農 村における健康管理活動のあり方として注目すべき点
であり，まことに有意義な報告であった。

\section{荤 血 I}

90. 農村における筫血の疫学的研究 第 1 報, 血液值の検討

91. 農村における筫血の疫学的研究 第 2 報, 健康状態の検討 千葉大・農医研 小 倉 敬一・他 1 名 千葉大・農医研 土 屋 和 子・他

92. 農村における筫血の疫学的研究 第 3 報, 環境諸条件の検討 千葉大・農医研 内 田 昭 夫・他

93. 長野県下農民の集団健康スクリーニングによる筫血検査の結果 長野県 佐久総合病院 横 山孝子・他 6 名

94. 愛知県海部地区の資血実態調査について 愛知県 海南病院 井上一夫・他 7 名

$\begin{array}{llllll}\text { 座長 } & \text { 熊本大学医学部教授 } & \text { 野 } & \text { 村 } & & \text { 茂 } \\ & \text { 岩手県 沢内病院長 } & \text { 加 } & \text { 藤 } & \text { 邦 } & \text { 夫 }\end{array}$

日本農村医学会資血研究班の，農村における資血の 疫学的研究の第 2 年度の調査報告が90, 91, 92 によっ てなされた。90は，全国33協力機関の測定した農村 婦人の血液値を, 調査地別, 農・非農別, に整理し, 北陸, 九州, 四国に低いこと, 冬季より夏季に低いこ となどを再認している。91は，これらの被検対象につ いて, $\mathrm{Hb} 12 \mathrm{~g} / \mathrm{dl}$ 末満者, $10 \mathrm{~g} / \mathrm{dl}$ 末満者の自他党症, 既往などを観察し，消化器疾患の既往のあるもの，経 産婦，低血圧者に筫血の多いことなどを認めたが，さ らに，農村では無自党筫血の存在に注意する要のある ことを指摘している。92は, 自然的, 社会的環境諸要 因と血液レベル，とくに筫血 $(\mathrm{Hb} 12 \mathrm{~g} / \mathrm{dl}$ 未満) 出現率 を検討し，年間 200 日以上の農業労働従事者群に筫血 者は多く，しかも，農業経営規模別にみて，むしろ規 模大なるものに筫血者が多いとの結果を得ている。ま た，動物蛋白摄取の少いものに筫血出現率が高く，筫 血の要因としての労働と栄養についての知見を加えた。

93 は, 79 で報告した長野県下における集団健康スク リーニングの試みにおける筫血検査の結果について報 告した。この被検者の血液水準は, 内田らの報告から
みれば，よい方に属するが, 胃腸疾患既往者に筫血者 が多く, また, 肥満者には少ない傾向など, 全般的に は内田らの報告と同様の傾向である。血清鉄の測定に ついては, 測定試料の採血時刻による個体内変動に 注意しているが，これはやはり従来からいわれるよう に午前中の採血試料を用いるよう留意することが望ま しいだろう。また, 正常 $\mathrm{Hb}$ 量で血清鉄の低值を示す 例の少なくないことに注目しているが，かつて Beutler や永山が注目した, これらの低血清鉄者の自他覚症や 生活機能は今後さらに明らかにされる必要がある。

なお，この横山の報告においても，内田の報告でも， 被検集団の居住地の高度と血液水準の関連が指摘され， 高度 $5 \sim 600 \mathrm{~m}$ 以上では, 筫血出現率が低下するので はないかとみられたが, 高原の場合, この高度に居住 ること自体に関係するのか, 高地の営農や生活形態に 関するのかなど, さらに検討を要する問題である。昭 和 35 年頃, 血液学会の共同研究もあるが, なお, 今日 の標準化された測定方法技術でさらに追及することが 期待される。

94 は, 低地, 愛知県海部地区の鍋田開拓農村の資血 
$612(62)$

実態調査について栄盖摂取状況とともに報告したが, 血色素レベルは佐久と対照的で, 筫血出現率は高い。

これらの演題に関連して，柳沢(東京医歯大)は，農 村における筫血の成因を考える場合に，労働や食生活 条件など社会的要因の関連を分析することも，もちろ ん必要であるが，それのみに眼をうばわれることなく， 筫血の本質的な生理，病理にも眼をくばって，公衆保 健と医療の両面からのアプローチによって筫血対策が
進められるべきだとの追加発言があった。

社会集団における血色素レベル(筫血)をみることの 意義，おなじく筫血という用語の中にある，病的，臨 床的な筫血症 (本態的または続発性筫血)の概念, 生活 指導の対策となる筫血者の様態など，この数年，しだ いに整理されて理解されるようになり，また，対策も 進められてきているようにみられる。

\section{完 血 II}

135. 農村婦人の貧血に関する研究，とくに血色素量と季節変動・血清鉄・農業形態との 相互関係について 徳島県 麻植協同病院 坂 東 玲 芳. 他 3 名

136. 過去 3 年間の農村血液検診の成果と問題点について

静岡県 静岡厚生総合病院 赤 堀 菊 男・他 4 名

137. 健康管理地区（中川町無医地区）住民の筫血について

138. 農山村における学童の貿血実態 北海道 旭川厚生病院 杉 村蓆・他 5 名 愛媛県 広見町健康センター 新田 則之・他 2 名 139. 農村貧血症の臨床疫学的研究，(第 2 報）循環機能検査成績について(1)

日本女子衛生短大 岡 田芳 子

$\begin{array}{llllll}\text { 座長 } & \text { 千葉大学医学部教授 } & \text { 内 } & \text { 田 } & \text { 昭 } & \text { 夫 } \\ & \text { 熊本県健康管理協会専務理事 } & \text { 小 } & \text { 山 } & \text { 和 } & \text { 作 }\end{array}$

農村における筫血の問題は, 農村医学会のメインテー マの一つである。毎年演題が多数提出(本学会10題)さ れることは，まだまだ解明しえない多くの問題をかか えていることの証左である。いわゆる農村の筫血が, 139 の題名にある「農村筫血症」なるものかどうか, 疫学的にも, 臨床病理学的にも, 今後究明されねばな らぬ課題と思われる。名称はともあれ，農村における 筫血問題の解明は本学会の重要な使命であり, 責務で もある。

135 は, 対象集団によって, 筫血出現率の差が著し いことを述べ, 原因の追究として, 季節変動, 農業労 働，生活状況との相関を求めた。血液所見に季節変動 があることはほぼ定説化しているが，年間を通じて休
養のとり難い酪農家と，コントロールの病院職員と対 比させて調査し, 酪農家婦人に, 8 月の酷暑期の資血 化傾向が著しく，酷暑と労働の二重負荷が原因である とした。しかし，冬期に血清鉄が大きく上昇している のに $\mathrm{Hb}$ その他がさほど増えていないことに, 内海(水 戸協同）旗問があり，その原因はわからない，上昇

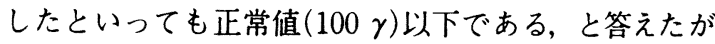
今後例数を增して検討する必要があろう。

136 は, 昭和 46 年から 3 年間の筫血調査より, 問題 点を挙げた。とくに, 46 年度の筫血者のうち 3 年後に 正常值に復したのはわずかに $19 \%$ に過ぎず，治療の不 徹底, 食生活の実情, 過労などによって血液性状が反 復しているので, 綿密な保健指導と経過観察が必要だ 
と強調した。これは農村における筫血の改善対策を論 ずるとき，常にぶち当たる困難な問題である。この演 題に関しては, データの出し方, 表現の仕方に理解困 難な所が目立ち，内田(座長)がその点を指摘した。

137 は, 昭和 44 年から 5 ケ年間の健康管理地区の男 性の $\mathrm{Hb} \cdot \mathrm{Ht}$ 值から, 50 才以上之未満を比較して; 50 才以上が有意の低值を示したと述べた。その原因の一 つに疲労を挙げ, 過重労働, 栄養摂取量の減少, 慢性 疾患に悩む者が多く, 悪循環になり, 筫血傾向が生じ たと報告した。これに対し，小倉(千大・農医研)およ び内田(座長)から，この筫血傾向は加令現象として説 明がつくのではないかと質問があり, 演者は他のグル ープのデータと比較して䞄血化傾向が著しいので, こ う判断したと答えたが, $\mathrm{Hb} \cdot \mathrm{Ht}$ の平均值だけで論じら れており，平均值は低下の傾向にあっても筫血という ほどでなく, また, 筫血者の実数も挙げてない為デー 夕の提示が不充分で議論が進まなかった。

138 は, 前題と同じく過疎化の著明な愛媛県農山村 の一地区の調査例である。健康破壊が母と子に表われ ていると指摘し, 小学生全員(約 150 名余)を, 昭和 47 年から 3 ケ年貿血検査を行なった。その結果, 学童に 貿血が多い事, 更に筫血の母親に筫血の子供が多い事 を述べ, アンバランスな食生活をはじめ, 生活環境が 密接に関係していること, 子供の筫血対策は母親の筫 血対策, ひいては地区での筫血対策が必要で, 学校保 健と地域保健の連携, 総合保健活動として推進されな
ければならない事を力説した。

139 は, 貧血者の循環機能検査成績を検討し, 高血 圧者群に比較して, 正常血圧者群に $\mathrm{Hb}$ 低下者が多い が, 高血圧者にも約 $30 \%$ の筫血を認めたこと, またさ らに，貿血があって高血圧が合併するものでは，心電 図, 眼底などの所見に異常出現率が高かったと報告し た。演題の農村筫血症の言葉が適当かどうか, 内海 (水 戸協同)より疑問が出された。演者は深い意味はないと して，これを改めることとした。また，大月（群馬・ 藤岡保健所)より, $\mathrm{Hb}$ 高値で高血圧合併グループの循 環器機能について, 坂東(麻植協同病院)より, 貧血, 高血圧と腎機能についての質問があったが, 検討結果 は令後にもちこされた。

総括的討議の中で, 柳沢文 (東医歯大) は, 農村の「過 重労働」なる表現に言及し, 変貌する農村, 省力化が 進む農村で, 過重労働という言葉を安易に使うべきで ないと指摘。農村の貧血の成因を簡単に栄養不良, 過 重労働にもっていけばよいというのではいけない。栄 養や労働を改善させようと意識的に使われる意味であ れば, 一応了解出来るが, 本当の農村の筫血を見うし なうのではないかと警告した。

おわりに, 138 の学童の貧血の問題指摘は重要であ る。しかも，直ちに母親の問題に結びつき，また，健 康会議や具体的・社会的対策がとられた事に敬意を表 したい。農村医学を志すものとして，一つのあり方を 示すものといえよう。

\section{ハウス病}

110. ビニールハウス内作業の生体に及ぼす影響, （Ｉ）生理学的検査について 三重県 中勢総合病院·瀬川善 樹・他 5 名

111. ビニールハウス内作業の生体に及ぼす影響, （II ）生化学的検査について 三重県 中勢総合病院 川 村 利 夫・他 5 名

112. 八ウス園芸作業に従事する農家主婦の循環器系の負担について

$$
\text { 久留米大·環衛 力 丸 健 · 他 } 4 \text { 名 }
$$

座長 弘前大学医学部教授 $⿴$ 一谷 三 郎

110，111は，前日に行なわれた宿題報告の一部をな すもので，八ウス内外で実験労作を負荷することによ
つて, その影響差を110は生理学的面から，111は生 化学的面から分析・検討しようとして実施されたもの 
である。

瀬川らは，八ウス内における実験労作の際の換気量, エネルギー消費量は八ウス外のそれに比べて有意に高 く，その程度は男よりも女に大であるとのべた。

また, 川村らは, 同じ実験における血液諸成分の変 化をハウス内外で比較検討した結果，八ウス内では副 督皮質機能の軽度光進をうかがえる成績が得られたと いう。

これら 2 題に対して一括討議を行なったが，110に ついては中村(長崎大・衛生)から，エネルギー消费量

の算定に誤りがある旨指摘された。

また, 110, 111 の両者についても中村から, ハウス 農民と一般人とでは温熱刺激に対する反応が異なると 思われるが成績に異なるところがないかとの質問があ ったが,これについては今回は基礎実験として実施し たので，十分配虑しなかった旨の解答があった。

実験の成否は条件設定の優劣に係わる面が非常に大 きい。八ウス農民に対する実験には適応生理学的な配 虑が必要であるが, 本実験では実験の時期, 被検者の 選定, 八ウス内滞留時間, 労作負荷時間, 負荷方法な どについてもう少し検討を加えていただきたい面があ つた。

また, 演者は, エネルギー代謝の結果から, 男に比 べて女の方がハウス内労働の負担が大きいのではなか ろうかと推察しているが, 耐熱性の性差については議 論の多いところで, 女は男に比べて発汗量が少ないか ら有利とする説と, 逆に皮下脂肪が厚く放熱が妨げら れるから体温調節上不利であり, また, 循環機能も男 よりも劣るから総じて不利であるとする説がある。今
後，资料を集積して大いに検討していただきたい。 ただし，自転車エルゴメーターは上下肢の長短とい つた体格的要素に支配されることが多いから，本題の 目的の一つかと思われるような性差の検討には階段昇 降負荷試験の方が better でなかろうかと思われた。

112 力丸らは, 福岡県のハウス農家の主婦の健診を 行ない，心電図所見で $\mathrm{T}$ の平低化をみたものを $20 \%$ に認めたことから，八ウス労㗢の高温馴化の循㻴系へ の負担を示しているものでなかろうかとのべた。これに 対して中村から，対照地域での資料の有無を問われた が，今回は調査していないので，前回調査時の資料か らみるとやはりハウス農民の方が高いように思われる 旨の回答があった。

今後資料を集積してさらに検討されることを期待し たい。

関連質問として, 藤井(北海道勤医協札幌)から，八 ウス農業が全農事に占める割合についての質問があっ たが，八ウス農業は地域差があり，経営専門家でない と概要の把握は困難な問題である。

ただ,これまでハウス栽培は野菜や花の栽培を中心 として南西地域に発達してきたが, 稲作における田植 機の導入によって水稲の八ウス育苗が寒冷地では普及 しつつある。八ウス栽培になれない人達が, この作業 に従事することによって今後は寒冷地にも八ウス病の 発生が懸念されるようになってきた。この意味で,こ の方面についてはますます研究を発展させてもらいた いし，また，これまでに得た成果を農家に還元するた めの指導をも併せ努めていただきたいと考える。 


\section{代謝・内分泌疾患}

113. 当院における糖尿病患者と肺結核との関連について

愛知県 北病院 伊 藤 恭 平 - 他 6 名

\section{4. 糖尿病治療に及ぼす保健婦活動の影響}

広島県 佐伯総合病院 高 科 成 良・他 2 名

115. 二，三外科的疾患における膠原代謝について

·秋田県 鹿角組合総合病院 谷 川武 史 - 他 4 名

*116. 上皮小体機能立進症における消化性溃瘃の発生について

秋田県 鹿角組合総合病院 岡 山尚. 史 ·他 3 名

座長 神奈川歯科大学教授 野 田 喜 代 一

本群の報告は, 113,114,115の 3 題であり, 113 と 114 の 2 題は糖尿病について, 115 は八イドロオキシ・ プロリン (HOP)についての報告であった。113 の伊藤 他は, 肺結核と糖尿病の合併について, 肺結核入院患 者の $7.3 \%$ に糖尿病が合併しており，その死亡率が 5 ケ年間に $23.7 \%$ ，その死因は血管障害と悪性新生物が ほとんどであったこと, 糖尿病先行者は, コントロー ル不良で，菌陰転化傾向が乏しく死亡率がとくに高い ことなどが注目すべき成績であった。合併例は肺結核 先行群ついで同時発見群が多いということであるので, 肺結核の治療食としての高カロリー食が, 糖尿病発病 の誘因となるのではないかという質問があり（内海・ 茨城水戸, 野田), 伊藤は遗伝因子の存在が重要であ るが，当然食事安静などの関連も考えられると答えた。 肥満の程度と糖尿病合併についての質問(内海)につい て伊藤は, “標準体重の 30 40\% 程度の増加者に多い とした。また糖尿病発見の動機についての質問(内海) に対して, 伊藤は, 肥満者の経過をおっての検査の励 行によるところが多いとした。なお，肺結核と糖尿病 合併率 $7.3 \%$ は, population surveyにおける糖尿病発 見率と大差ないのではないかとの質問(高科広島・佐 伯)に対して, 伊藤は field workでの発見率とほほ匹 敵すると答えた。

さて, 肺結核重症化の諸因子のうち, 合併症につい ては, かつては, 鈎虫症, 負血, 低栄養などが問題で あったが, 今日的課題として糖尿病がとりあげられた ことは意義が大きい。今後は, 肺結核・糖尿病合併例 の一層の追究と, 農・非農間の相違についてなどの研 究を通じて, 糖尿病の発症と経過とを支配する因子群
についての知見が明確になることを期待したい。

次, 114 の高科他(広島・佐伯)は, 糖尿病治療と保 健婦活動についてのべた。糖尿病患者は, まず原則と して教育入院し，退院後は約 1 ケ月に 1 回の通院治療 に加えて, 年 2 回程度保健婦が患者家庭を訪問し, と くに食事療法, 生活指導, 合併症などについて家族ぐ るみの教育指導を行えば, 糖尿病のコントロールが一 段とよくなるという成績を報告した。院内指導の方法 については (質問・伊藤), 高科は糖尿病患者カードに は食事のカロリー数などを記し，週 2 回家族ぐるみ出 席をもとめて糖尿病指導会を実施，また，月 2 回昼食 会を行って実際の献立を教育しているとのべた。

さて，今日の医療制度のもとでは，臨床医は多忙を きわめ, 患者との対話の時間は, 糖尿病のように食生 活をはじめとする生活指導が治療上もっとも大きな役 割を占める疾病においてすら，その余裕がなく，診療 はややもすれば技術的面のみにかぎられがちである。 保健婦活動の協力によって, 糖尿病患者が明らかによ い経過をとるということは, 今日のわたしたちの臨床 活動に重大な問題を提起するものである。すなわち, 糖尿病にかぎらず, 難治性疾患の治療全般に保健婦や パラメディカルの活動をくみこむことの価值について 示唆に富む報告をいただいたわけである。

115 谷川他(秋田, 鹿角)は, 八イドロオキシプロリン (HOP)を測定し, 二, 三外科疾患の膠原代謝について 報告した。HOP はアミア酸で, コラゲン中にのみ存在 し, その代謝を反映して, 血槳および尿中で増減し, しかも食飰中のたん白質には由来しないという特徴が ある。そこで, HOP はコラゲン代謝変動あるいは膠原 
病の示標として役立つということで最近注目をあびは じめている。本報告では, 甲状腺機能六進症, 癌の骨 転移, 実験的上皮小体機能六進症において, 尿中 HOP の排泄が増加することを認め, これらの疾患における HOP の診断上の価値を高く評価した。また，それらの 膠原代謝を知る上でも役立つと報告した。本席では追
加，質疑はなかった。

さて，HOP の測定は今日のところやや先進的であり， 臨床検査としては, 測定が面倒なため低いとのことで あるが，1日もはやく日常の臨床に使用できるよう， 今後の研究に期待したい。

\section{臨床・その他 I}

117. 農村地域における小児外科の現状……長野県 佐久総合病院 陶 易 王・他10名

118. 小児科病棟における問題点，特に長期入院患者の管理について

静岡県 静岡厚生総合病院 高 嶋 芳 樹 - 他 5 名

119. 農村地帯の精薄児中に占める染色体異常者の頻度

長野県 佐久総合病院 藤 田 公 生 - 他 1 名

座長 山口県 周東総合病院長 有 馬 和 雄

117 は，佐久総合病院の独立小児病棟における 12 年 間の小児外科部門の概況を疾患別にまとめて報告した。 疾患別では虫垂炎, ソケイヘルニア, 頭部外傷が多く, 虫垂炎は毎年 80 例位で大きな増減はないが, 穿孔例が 著明に減少した。ソケイヘルニアは逐年増加し手術年 令が低下した。これらは麻酔の進歩と共に一般の小児 外科への信頼感増大の反映と見られる。また，小児の 頭部外傷が 1962 年の 4 例より 1973 年には 75 例と激増 しているがその大半は交通事故で, 農村のモータリゼ ーションと共に交通災害が都市より農村に急速に拡大 していることを示した。腸重積は全身麻酔下のバリウ ムおよび空気注腸で整復されるようになって手術例は 激減した。総胆管輬腫, 総胆管拡張症の術後成績は良 いが胆道閉鎖の予後は問題があり，また，鎖肛や熱傷 についてもその問題点を述べると共に農村地域の小児 外科も疾患の種類と数で漸次都会化していると発表し た。質疑応答で同院の小児病棟は当初 60 床で始まり, 現在 120 床となっており, また, 独立小児病棟として 開設以来, 小児内科, 小児外科, 耳鼻科, 眼科, 産科 等各医師の連絡が非常に良くなったとの追加があった。 同院の小児病棟は総合病院附属小児病院の観があって 麻酔や術後管理の進歩と共に小児外科の内容の充実が うかがわれた。
118は，小児科病棟で最近慢性疾患が増加して，そ れに伴う長期入院による患児の精神面の管理の困難な 点を症例をあげて説明した。13 才の中学 1 年の女児が ネフローゼで 1 年以上の入院中に症状の悪化や他患者 の不幸な例を見たりして漸次感情の起伏が大きくなり 自暴自棄となったが, 環境を変えたり病気を理解させ ることに努力した結果, 落付いてきて再び明朗になっ た。 3 才の男児が禾球体腎炎で入院したが 6 週間位で 反抗的暴力的となり，母親とも離れられなくなって遂 に通院治療に切換えざるを得なくなった。これらの例 に見るように長期入院患児は精神面でいろいろの変化 を起こしがちであるが，小児専門病院と異なり総合病 院の小児病棟では患児を年令別或いは疾患別に病室単 位に収容するほかないが，それも部屋の都合等で必ず しも理想どおり運営出来ない。そうした中で保母を中 心として幼児の集団保育や学童の勉強等を取り入れて 長期入院による心の歪みを取り除こうと努力している 実情を報告した。質疑応答では, 静岡厚生総合病院の 小児科病棟は小児内科だけであるとの追加があった。 また，陶は，佐久総合病院では今年から小学校の分室 が出来て先生が 2 名常勤して病棟附属の教室で授業を しているとの追加を行った。小児科患者の質的变化に 伴って長期入院の增加傾向が著しい現状下で患児の精 
神面の管理の困難さを各病院とも痛感している時に, 高嶋等はその対策を示して今後への大きな示唆を与えた。

119 は, 農村地帯の精神薄弱児収容施設の全員を対 象として染色体分析を行い，その成績を発表した。59 例中に 11 才の $45 \mathrm{X} / 46 \mathrm{XX}$ のターナー症候群モザイク 型, 18 才の $47 \mathrm{XXY}$ のクラインフェルター症候群の 2 例の性染色体異常と, 7 才の $47 \mathrm{XX}+21$ ダウン症候群, 7 才の $47 \mathrm{XX}+\operatorname{mar}$ 部分的 18 トリソミーの 2 例の常染 色体異常を発見した。周東総合病院では染色体分析を 山口大学小児科に依頼しているが, クラインフェルタ
一症候群, ダウン症候群が多いと聞いているとの追加 に対し, 藤田は, 小児のダウン症候群は確かに多いが, 今回調査した施設では 59 人中 1 例のみで意外に少なく 農村地帯ではまだダウン症候群はかなり短命に終って いるのではないか(施設収容年令以前に死亡している) と推論していた。また, 佐久総合病院でダウン症候群 が 14〜15例あったが母親の保菌者はなかったとの追加 があった。第一線の病院で染色体分析にまで進んでお られることに心より敬意を表するとともに，今後一層 の御研究を期待したい。

\section{臨床・その他 II}

120. 眼科領域における老令者の入院時管理について

静岡県 遠州総合病院 大河内 雄幸 - 他 3 名

*121. 秋田県農村における角膜移植の現況

秋田県 平鹿総合病院 伊 藤 昭一・他 1 名

122. 最近 2 年間における外眼部感染症の起炎菌について

長野県 佐久総合病院 藤 田 邦彦・他 2 名

123. 農業従事者の早老に関する研究（農民の血清 $\mathrm{SH}$ 基量測定）

$$
\text { ·秋田県 平鹿総合病院農医研 三浦修・他 } 3 \text { 名 }
$$

124. 農村地域における頭部外傷の現状——佐久総合病院脳外科の症例から一

長野県 佐久総合病院 柳 沢 昭 吾 - 他 8 名

125. 重症成人水痘症の 1 例

愛知県 愛北病院 大原 清 仁・他 5 名

座長 静岡県 静岡厚生総合病院 平。田史子 秋田県 十文字町西成辰雄
120 の「眼科領域における老令者の入院管理」では， 白内障をはじめとする患者の約半数は合併症を有し， 全身検査, 早期離床, 内科との混合病棟等によって偶 発症の合併に対処しているが，122(長野·佐久)から， 他科に比して眼病に対する病棟での看護処置について 質問があり，眼科領域の教育は比較的よく行われてい るとのことであった。老令者の入院の增加する中で, 局所検査のみでなく全身検査を行い，内科領域とも連 けいをとり，早期䧺床によって精神的肉体的負担を軽
減することが今後さらに必要な事柄である。

122 の最近 2 年間の外眼部感染症の起因菌」で は. 208 例の眼疾患の培養を行い, また, 感受性検査 によって治療を検討しているが, 大河内から外麦粒腪 に対する抗生物質点眼の効果, 排菌時の抗生物質の使 用について質問があり， $\alpha$-streptococcus が多く, CM 点眼, ジョサマイシン投与を行い, 1 週で治癒しない ものは来院させているとの回答があった。本報告は外 眼部疾患の起因菌の動態について詳細に検査, CM の 
$618(68)$

有効率の高いことが確認されたこと，また，無効例に 対しては $\mathrm{GM}, \mathrm{KM}$ の使用を検討すべきことなど，こ の領域での治療で有用な報告であった。

123 の「農業従事者の血清 S H 基測定」では，年 令と有意の逆相関関係を得, また, 平地農村より農山 村に低下が大きいことなどを指摘した。先回報告の海 岸部と農村部婦人の測定値にふれて, 柳沢 (自治医大) から，山村婦人が漁村婦人より老化が早いというが, 一般に山村以上に漁村に僻地性が強く，その点も今後 綜合して検討して欲しい旨の発言があり，また，野田 （神奈川歯大）は，農村の方がより早老であることは多 分栄養の問題であろうと考えられ，かつて米作地帯農 村, 漁村, 東京郊外農村についての調査では, 三者と も労働量は大差ないが, 農村の栄養量がもっとも劣悪 であったとの発言があった。森岡(日大)は, $\mathrm{SH}$ 基で どの程度に老化の基本的な指標となると考えるか，ま た，老化区分に用いた SEは何かとの質問があり，演 者および同研究所小棚木から, SH 基減少を老化と断 定しているのではなく，その指標を示す一方法と考え 基礎的に検討しており，老化に用いた $-\mathrm{SE},-2 \mathrm{SE}$ は回帰曲線の誤差範囲 $\left(S Y \sqrt{1-Y^{2}}\right)$ との回答があり,
また, 中村(長崎大)から相関比をとってみてはどうか, また，他の血液值，例えばコレステロールなどとの関 係は如何との発言があった。これに対して林（秋田・ 平鹿）から, 海岸部に比し山間部が低蛋白, 高含水炭 素食で, 脂質では低コレステロール，高中性脂肪で筫 血者が多く．これらが老化に関係があるかも知れない との発言があった。血清 $\mathrm{SH}$ 基の測定は老化を知る手 がかりとして有力な方法と考えられ，これらの事柄を 含め, さらに検討を続けるべき問題と考えられる。

124 の「農村地域における頭部外傷の現状」では, 2 年間の患者を荒木分類, 原因別に集計, 交通事故が $73 \%$ に及ぶこと, 男性に多発すること, 半数以上に合 併症を有すること, 墜落事故, 農山林作業に上る事故 も少なくないことを整告，農村における医療体制を含 めて検討を続けるべき問題である。

125 の, 成人の罪患がきわめて稀とされる「重症 水痘症の 1 例」についての報告では, その症状経過の ほか仮痘との臨床的鑑別についても述べ, 感染症が農 村でも変化している様相について言及しており注目さ れる症例であった。 